\title{
Risk analysis of the agri-food supply chain: A multi-method approach
}

\begin{abstract}
Agri-food supply chains (AFSCs) are becoming more complex in structure, and thus more susceptible to different vulnerabilities and risks. Therefore, to enhance performance, we need to manage the risks in AFSCs effectively and efficiently. This study analyses various AFSC risks using a multi-method approach, including thematic analysis, total interpretive structural modelling (TISM) and fuzzy cross-impact matrix multiplication applied to classification (MICMAC) analysis. Based on the empirical data collected from experienced AFSC practitioners and following thematic analysis, eight categories of risk and 16 risk factors were identified as important. Furthermore, the interrelationships among the identified risks were built using TISM. Finally, the identified risks were classified into various categories according to their dependence and driving power using fuzzy MICMAC analysis. The research results indicate that the weather-related and political risks have the highest driving power and are located at the lowest level in the TISM hierarchy. These risks have a high tendency to disturb the whole flow of AFSC and so should be managed effectively. This study advances existing literature on identifying risk factors, defining interrelations between different AFSC risks, and determining the key risks. The risk analysis results can help AFSC practitioners in AFSC to identify, categorise and analyse the risks.
\end{abstract}

Keywords: agri-food supply chain; risk identification; thematic analysis; total interpretive structural modelling; fuzzy MICMAC

\section{Introduction}

Agri-food supply chains (AFSCs) are the linked events in the agricultural production of food, which involves all stages of production, processing, trading, distribution, and consumption namely, "from farm to fork" (Food and Agriculture Organization 2018). Since these supply chains are responsible for providing sustainable, affordable, safe and sufficient food, feed, fibre and fuel to consumers, it is critical to ensure that they operate smoothly and successfully in the increasingly volatile business environment (KPMG 2013). However, designing such smooth and stable AFSCs is extremely difficult for operation managers due to the involvement of various risks and risk-driving factors (Diabat et al. 2012; Esteso, Alemany, and Ortiz 2018).

An AFSC risk is defined as "the possibility of breakdowns, operational difficulties, and credit loss and economic losses due to various uncertain factors during the operation process of each and every nodal enterprise along the food supply chain" (Septiani et al. 2016, 52). Because of the increased complexity of international supply network relationships along with greater uncertainty in supply and demand, customer preferences have shifted to higher quality products, more strict quality and safety standards, short shelf-life of agri-food products, lower costs and less dependency on climatic conditions. Subsequently the number of risks has increased (Baryannis et al. 2019; Leat and Revoredo-Giha 2013; Siddh et al. 2017; Vanalle et al. 2019). In an AFSC, risks are mostly related to weather, biological/environment (e.g., excess rainfall, pests, and diseases), logistical/infrastructure, market (e.g., labour shortage and volatile customer demand), policy/regulation, financial, and operational/managerial factors (Nyamah et al. 2017; Behzadi et al. 2018). These risk sources could disrupt the flow of goods and services, reduce the quantity of agri-food products, interrupt access to international markets, and further threaten the performance of the AFSC. To address the AFSC's vulnerabilities and risks, various academics and practitioners have emphasised the need for the management of AFSC risks from different perspectives such as risk identification, risk assessment, decision analysis, risk 
mitigation and contingency planning (Tang and Tomlin 2008; Ge et al. 2016). Mitigating AFSC risks will aid farmers, processors, distributors, wholesalers and retailers to increase product freshness and the reliability of distribution services and decrease stock-outs and inventory levels (Ahumada and Villalobos 2009). However, most of the existing literature focuses on technical methods and capability to perceive, prevent, mitigate and avoid diverse vulnerabilities and risks (Bachev 2017), with little research evaluating the interrelationships among different AFSC risks (Ho et al. 2015).

The study undertakes a comprehensive analysis of AFSC risks by identifying various risk factors, structuring interrelationships among them, and distinguishing key risks. Thus, three research questions are formulated: (1) What are the main risk categories and risk factors in the AFSC? (2) How are the identified risk factors interrelated? (3) What are the risks most adversely influencing the AFSC? By answering these research questions, this study provides insights into risk identification, classification, and factor analysis, and makes the following contributions. First, it enriches the AFSC risk management literature by serving as a systematic guideline for academics and practitioners to identify, categorise and analyse AFSC risks. Second, it will help AFSC practitioners to formulate different strategies to mitigate risks based on their classification and interrelationships. Third, some key risk management decisions could be made based on the identified key risks.

The remainder of this paper is organised as follows. In section 2, AFSC risks are identified through a comprehensive review of the literature. Then, the research methodology is discussed in section 3. The data collection process is presented in section 4 followed by data analysis and findings in section 5. Sections 6 and 7 are dedicated to the discussion and contributions, respectively. Finally, we draw conclusions and future research directions in section 8 .

\section{Literature review}

Generally, there are risks hidden in all business activities (Pfohl, Gallus, and Thomas 2011), with AFSCs facing more challenges due to their unique characteristic - perishability. Namely, AFSCs' managers need to coordinate management activities efficiently and effectively to maintain the quality and other performance standards (Moazzam et al. 2018). However, this is a difficult task as risks may arise from diverse factors. For example, defective and risky products may be recalled because of contamination, with such recalls proving costly and detrimental to firms' reputation and service quality (Marucheck et al. 2011). Simultaneously, risks may emerge in different AFSC stages before the consumption of the final products such as production, storage, processing and distribution (Nakandala, Lau, and Zhao 2017; Zhou et al. 2019), with significant and adverse effects on the supply chain performance (Blackhurst et al. 2005; Yang and Yang. 2010; Macdonald et al. 2018). The production process is associated with biological production, which is affected by weather variability, pests and diseases, seasonal factors, and price variability (Weintraub and Romero. 2006). In the processing stage, there are special risks associated with food quality and safety (Esteso et al. 2018). For example, contamination is the most serious of food safety-related risks that may occur in the production and processing stages, and may involve incidents that could constitute a public health emergency of domestic or international concern (Dani and Deep 2010). In the distribution stage, the agricultural market is particularly volatile and heterogeneous, and extremely sensitive to economic and financial fluctuations (Borodin et al. 2016). Further, the seasonality, supply spikes and perishability attributes of agri-food products may cause substantial loss of product value if not properly handled in the packing, storage, and transportation processes (Behzadi et al. 2018). Therefore, it is crucial to develop a typology with a structured and detailed collection of risks for definitive risk analysis and management. 
The literature offers various definitions of supply chain risks (Wagner and Bode. 2006; Bogataj and Bogataj. 2007), with most either focusing on a specific function (Juttner, Peck, and Christopher 2003) or an element of the supply chain (Zsidisin 2003; Ellis, Henry, and Shockley 2010), and not considering the whole chain. This study uses the supply chain risks definition proposed by Ho et al. $(2015,5035)$ to identify risks in the AFSC:

the likelihood and impact of unexpected macro and/or micro level events or conditions that adversely influence any part of a supply chain leading to operational, tactical, or strategical level failures or irregularities.

Potential risks in supply chains can be categorised according to different perspectives (Rao and Goldsby 2009; Rangel, Oliveria, and Leita 2015) such as low/high probability risks, high/low consequence risks, and internal/external risks (Kleindorfer and Saad 2005; Kumar, Tiwari, and Babiceanu 2010). Besides, some studies have divided risks into three categories internal, network-related, and external risks (Lin and Zhou 2011). Further categorisations of risks are provided by Mason-Jones and Towill (1998) and Christopher and Peck (2004). Risks are classified into five types: (1) internal to the focal firm, which are process and control risks; (2) external to the focal firm, but internal to the supply chain network, which are demand and supply risks; and (3) external to the supply chain network, which are environmental risks. While all these risks are relevant to the AFSC, operational and disruption risks of supply/demand are particularly pertinent (Behzadi et al. 2018). Considering the aforementioned arguments, three steps are followed to categorise the risks. First, we adopt a broad view on supply chain risk management (SCRM) to build a generic understanding of the risk categories and match various risk factors with appropriate categories. Second, we focus on AFSCs and add new categories to evaluate which risk factors should be incorporated or removed, and why. Third, we conduct pilot interviews with experts to further refine the results. Thus, the identified AFSC risks fall into nine categories: supply, demand, biological and environmental, political and macroeconomic, weather-related, logistical and infrastructure, policy and regulatory, financial, and management and operational risks (Jaffee, Siegel, and Andrews 2010; Nyamah et al. 2017). Table 1 summarises some of the most widely used research methods in the AFSC risk research.

\section{Insert Table 1}

Furthermore, various quantitative and qualitative research methods are applied to assess, control and mitigate the negative effects of AFSC risks, including mathematical programming (Laeequddin et al. 2009), quantitative survey analysis (Wagner and Bode 2006), interpretive structural modelling (ISM) (Diabat et al. 2012), analytic hierarchy process (AHP) (Guan, Dong, and Li 2011), and case analysis (Leat and Revoredo-Giha 2013). Although all these methods have their advantages in analysing AFSC risks, each one has its own limitations. For example, AHP cannot effectively evaluate risk and uncertainty because it presumes the relative importance of risks (Chan and Kumar 2007), while ISM only provides answers to the "what" and "how" questions but is unable to answer the "why" in theory building (Jena et al. 2017). However, it is interesting to note that although total interpretive structural modelling (TISM) has an advantage over ISM in answering the "why" question, and has been applied in different areas such as cloud computing (Amma et al. 2014), construction (Sandbhor and Botre 2014), flexible manufacturing systems (Jain and Raj 2015), and smartphone manufacturing ecosystems (Jena et al. 2016), to date, no study exists on the agri-food industry that has used TISM to identify the interrelationships among different AFSC risks. Qualitative methods are 
mainly used for identifying or categorising risks and constructing SCRM ideas (Cavinato 2004), whereas quantitative methods are used for risk assessment (Sodhi 2005).

Based on the literature review, we identified a number of research gaps, which open avenues for further research:

1. Although AFSC plays an important role in the world economy as a key source of food supply, there is significant lack of empirical studies that identify AFSC risks. Recent literature review articles on SCRM such as Ho et al. (2015) showed that only 10 papers out of 90 considered the risks in AFSC, indicating a clear demand for research on empirical AFSC risk analysis.

2. The existing work has mainly focused on the risk analysis, assessment, and mitigation. However, studies defining the correlations among different AFSC risks remain lacking (Ho et al. 2015; Behzadi et al. 2018). More research is required to explore the interrelations among various AFSC risks since the hidden effects of one risk related to other risks may cause substantial damage to AFSCs (Chopra and Sodhi 2004).

3. Most of the existing literature uses a single method, adopting either a qualitative or a quantitative approach. For example, the aforementioned studies (Ritchie and Brindley 2007; Dani and Deep 2010; Christopher, Mena, and Yurt 2011; Moazzam et al. 2018; Zhou et al. 2019) largely applied qualitative methods for risk mitigation and assessment. They focused on either examining the implications of risk factors or summarising risk mitigation methods. Only two studies (Diabat et al. 2012; Micheli, Mogre, and Perego 2014) adopted a case study approach and ISM to investigate the impact of one risk on another from an agri-food company perspective rather than from the whole AFSC perspective. Combining these two qualitative methods poses some limitations to identifying the causes in theory building because the causality between different risks cannot be explained. Furthermore, from 2003 to 2013, the number of studies using quantitative methods was almost four times the number of those applying qualitative methods in the SCRM field (Ho et al. 2015). Thus, there is a need to explore the integration of multiple qualitative approaches to tackle the complexity of AFSC risks.

The novelty of this study resides on the empirical investigation of AFSC risks in four countries over one year, which enriches the empirical literature on these risks. Additionally, we adopt a rigorous methodology and use multiple data analysis techniques. Further, we investigate the interrelationships among AFSC risks. The findings of this study help to fill the aforementioned research gaps.

To fill the research gaps in the existing literature, we analyse the risks by defining the interrelationships among risk factors and revealing the impact level of each risk using a multimethod approach with empirical data collected from experienced AFSC practitioners across Argentina, France, Italy and Spain.

\section{Research methodology}

This study adopts interpretivism to gain a deep understanding of the phenomenon and its complexity in its unique context (Creswell 2014) by accepting multiple viewpoints of different individuals from different groups (Saunders, Lewis, and Thornhill 2015). Thus, interpretivism is more suitable than other research philosophies for investigating complex issues and management realities. As an AFSC is a complex web of interconnected entities working 
collaboratively to make food available for consumers (Dani 2015), a comprehensive and deep understanding of AFSC risks can only be reached by probing AFSC practitioners' thoughts, values, prejudices, , views, feelings and perspectives (Wellington and Szczerbinski 2007; Morehouse 2011). Therefore, interpretivism is appropriate for this study. Researchers believe that there is a tight connection between interpretivism and inductive reasoning (Silverman 2000; Willis 2007). Quantitative approaches are largely based on deductive reasoning, while qualitative approaches are based on inductive reasoning. Qualitative research has been approved as an effective strategy to study participants' meanings and the relationship between them by using a variety of data collection techniques and analytical procedures (Saunders et al. 2015), whereas quantitative research has proved useful for testing objective theories by examining the relationship among variables (Creswell 2014). Furthermore, qualitative research allows researchers to investigate the participants' inner experiences and to figure out how meanings are shaped through and in culture (Corbin and Strauss 2014). Thus, we adopt a qualitative approach, rather than a quantitative one in this study to obtain the AFSC experts' opinions on the AFSC risks, understand how these risks influence each other, and identify the key risks, since it is difficult to capture such opinions using quantitative methods. Figure 1 illustrates the research methodology framework for this study.

\section{Insert Figure 1}

\subsection{Data collection method}

The semi-structured interview is the most widely used interviewing format for collecting empirical data, particularly for answering questions that are either complex or open-ended (Dicicco-Bloom and Crabtree 2006). A critical advantage of semi-structured interviews is their ability to reveal unknown information/knowledge (O'Keeffe et al. 2016). When interviewees are provided with sufficient opportunities to speak freely, novel information/knowledge can emerge (Saunders et al. 2015). Compared with other interviewing formats such as structured and unstructured interviews, the semi-structured interview is well suited to the exploration of the perceptions and opinions of respondents regarding complex and sometimes sensitive issues. It also enables the researcher to probe for more information and clarification of answers (Barriball and While 1994). Thus, the semi-structured interview is selected in this study to obtain AFSC managers' opinions regarding AFSC risks. To collect valid and complete data during the interviews and gain an understanding of the explored subject domain, a review of the existing literature on AFSC risk identification, classification, assessment, and mitigation was conducted before the empirical data collection. Then, an interview guide was developed. After identifying potential respondents, pilot interviews were conducted before empirical data collection. Additional risk management documents such as risk memos, solution designs, enterprise brochures, and functional documents were collected as replenishment of data sources to achieve triangulation.

\subsection{Data analysis methods}

The empirical data collected through semi-structured interviews were analysed using a combination of three methods - thematic analysis, TISM, and fuzzy MICMAC analysis. The multiple data analysis method adopted in this study helps to unpack different possible meanings from a single dataset (Clarke et al. 2015), as well as to balance the strengths and limitations of 
individual methods against each other (Frost et al. 2011). Thematic analysis is a qualitative data analysis technique used "for identifying, analysing, and reporting patterns (themes) within data" (Braun and Clarke 2006, 79). It helps researchers to conduct qualitative analysis independently and reliably (Vaismoradi, Turunen, and Bondas 2013). In addition, it has three distinct advantages; (i)it can summarise key features of a large body of data with a minimum description, (ii) it can highlight similarities and differences across data sets, and (iii) it can generate unanticipated insights (Braun and Clarke 2006). Compared with other qualitative data analysis methods such as discourse analysis and conversational analysis, thematic analysis is a clear and uncomplicated method that does not need theoretical details and technical knowledge (Javadi and Zarea 2016). Thus, thematic analysis was selected as the first data analysis technique to reveal risk themes.

Next, TISM was chosen to build interrelationships among the identified AFSC risks since it is an effective approach to establishing interactions among various elements and their degrees of association (Jayalakshmi and Pramod 2015). Sushil (2012) points out that TISM is a well-developed method and has been extensively used in different contexts for building relationships among different elements (also see Yadav and Sushil 2014; Jain and Raj 2015). TISM is a technique that evolved from interpretive structural modelling (ISM). Both ISM and TISM can identify the interrelationships among the considered variables; however, the interpretation for direct links is comparatively weak in ISM and may misrepresent the entire decision-making process (Jena et al. 2017). Other methods such as DEMATEL (Decision making trial and evaluation laboratory), graph theory, ANP (Analytic network process) and SEM (Structural equation modelling) can be employed to reveal the interdependence among the factors, but due to their drawbacks, they cannot be applied in this study. For example, DEMATEL is limited in dealing with problems of uncertainties and the bias associated with human judgement ( $\mathrm{Si}$ et al. 2018); graph theory is limited in deciding the direction of relationships between factors (Bondy and Murty 1976); ANP has limited applicability due to its complex procedure,; and SEM needs a large sample size (Mangla et al. 2018). Thus, TISM was selected to transform poorly articulated mental models into well-systematic forms. Consequently, it helped answer all of the theory-building questions (Yadav and Sushil 2014).

Finally, the fuzzy MICMAC analysis was used to identify the key risks in various categories based on the influence of the risks and to validate the TISM model of AFSC risks. The MICMAC analysis was initially developed to investigate binary types of relationships among different elements. To increase the sensitivity of the MICMAC analysis, the fuzzy set theory was introduced as an additional input of interaction possibility among the elements (Bhosale and Kant 2016). The inclusion of fuzzy set theory in TISM-MICMAC can be beneficial when a large number of elements are included for analysis (Yadav and Desai 2017). Currently, 16 AFSC risk factors are included in the present research work. Compared to the conventional MICMAC analysis, the fuzzy MICMAC analysis can analyse the interrelationships among elements precisely. Although there are other methods such as IRP (Interpretive ranking process) and AHP can assist in determining the relative importance of factors, they either fail in the aspect of consistency in experts' feedback or have limited applicability for pairwise matrices of more than 9x9 (Mangla et al. 2018). Thus, the fuzzy MICMAC was selected as it can critically analyse the scope of each element by considering the strength of the relationships among them (Bhosale and Kant 2016).

Considering the advantages offered by thematic analysis, TISM, and fuzzy MICMAC analysis, these approaches were combined together to analyse the AFSC risks in this study. 


\section{Empirical data collection}

This study collects empirical evidence from experts who have been involved in AFSC risk management. The semi-structured interview was used to collect data on AFSC risks. Thus, an interview guide was developed to keep discussion on the topic on track, and the questions focused on obtaining the participant's opinions on the AFSC risk sources they have experienced. The interview guide consists of five sections (see Appendix A). It first seeks general information about the interviewee and the company, and then asks specific questions about the relations with upstream and downstream companies. Additionally, two specific sections ask about the risks that the company and the whole AFSC have faced. Finally, questions are asked about how risks are mitigated. Interviewees could express their ideas freely regarding the context being discussed. Furthermore, many probing questions are asked to get interviewees to clarify their answers as necessary.

Purposive sampling and snowball sampling (Saunders et al. 2015) were used in this study to recruit suitable participants. Purposive sampling was performed initially to identify suitable participants who were thought to be knowledgeable about AFSC risks. Criteria for recruiting suitable participants were: (1) The participants should come from the agri-food industry and be directly involved in AFSC risk management; (2) they must have more than 10 years' working experience in AFSC risk management to ensure a high level of knowledge and experience; and (3) the selected company must be either a medium- (from 10 to 249 employees) or large-sized company (more than 249 employees), since these companies have rich experience and deep understanding of managing AFSC risks. Normally, there are no criteria for the sample size because they depend on the complexity of the research questions, the interview topic, the diversity of the sample, and the nature of the analysis (Saunders et al. 2015). Francis et al. (2010) suggested at least 10 interviews should be conducted in the initial sample analysis. As a first step, 14 participants were selected using a purposive sampling technique. The data collection process started with a wholesale distribution company in southern France which is a focal company in the local AFSC and has good connections with local upstream and downstream partners. Afterwards, we used snowball sampling to identify additional participants. Based on the criteria for recruiting participants (see above), some companies were found not unsuitable for this study, which resulted in only two potential participants being identified. After conducting further two interviews, new themes did not emerge, indicating data saturation point; thus, we stopped conducting further interviews resulting in a total sample size of 16 participants. Detailed information of each interviewee is shown in Table 2, including the interviewees' countries and companies, their positions in their companies, and the roles and responsibilities of their companies in the AFSC.

\section{Insert Table 2}

The interviews were conducted between April 2017 and July 2018 in four countries France, Spain, Italy and Argentina. The agricultural output of France, Spain, and Italy accounts for $16.7 \%, 12.1 \%$, and $11.7 \%$, respectively, of the total agricultural output of the 28 European Union (EU) countries (European Commission 2018). In the case of Argentina, the whole agroindustrial transformation sector is estimated to be 32\% of GDP (Regunaga and Tejeda Rodriguez 2015). The important role of agriculture in these four countries provides a good opportunity to explore AFSC risks. As these four countries are located in both the southern and northern hemispheres, we considered it worthwhile to visit them to investigate potential risks. In the summer and autumn seasons, AFSC practitioners in the four countries experience more biological and environmental, weather-related, and logistical and infrastructure risks. However, 
they experience more supply and demand risks in the winter and autumn seasons. The interviews with managers, directors and middle management in the agri-food industry provided a robust opportunity to explore risks in depth and allowed interviewees to elaborate on specific risks and problems, and implementation practices they employed to reduce risks. A copy of the interview guide was sent to the interviewees three days before the interview session, which gave them a clear understanding of the questions they may expect in the interview. Interviews lasted for 60 to 90 minutes on average with the interviewees being encouraged to express themselves on any questions asked to facilitate the revealing of new concepts.

\section{Data analysis and findings}

This section presents the mechanism by which thematic analysis of the data collected from the semi-structured interviews generates various themes (risks). Then, the TISM method is applied to model the interrelationships among the identified AFSC risks. Finally, the fuzzy MICMAC analysis is performed to analyse the dependence and driving power of AFSC risks in order to identify the key drivers of risk.

\subsection{Themes (risks) generated through thematic analysis}

The thematic analysis conducted here consists of six steps, as shown in Figure 2: familiarisation with data, generating initial codes, searching for themes, reviewing themes, defining and naming themes, and producing the report. Verbatim transcriptions were carefully read and edited to ensure the removal of irrelevant data, and then the initial codes were generated. To achieve reliability, two coders were involved in the process, which resulted in an intercoder reliability of $k=0.81$ (Cohen 1960). All coded data were validated by the companies that were involved in the semi-structured interviews to ensure the integrity of the results derived from these interviews and risk memos. The next step involved searching for themes through evaluating the relationships between codes, between themes, and between main themes and sub-themes, and then sorting and organising all relevant codes into potential themes until all possible themes, sub-themes, and related codes were generated. Afterward, we checked whether themes were suitable for the extracted codes and the entire dataset, generating a thematic map. After reviewing the themes, an ongoing analysis was performed to ensure that there were clear definitions and names for each theme. Finally, we selected vivid, compelling extract examples to produce an analysis report.

\section{Insert Figure 2}

We used first- and second-order codes, as proposed by King and Horrocks (2010), while generating risk themes. (1) Descriptive coding (first-order codes): the transcript data from interviews were allocated to suitable descriptive codes. (2) Interpretive coding (second-order themes): the descriptive codes that seemed to have some common meanings were grouped together, with an interpretive code created to capture them. (3) Overarching themes (aggregate dimensions): a number of overarching themes that characterised the key concepts in the analysis were identified.

Table 3 presents an overview of the empirical evidence for different risk types, linking first-order codes, second-order risk factors, and the supporting evidence from each interview case. The first-order codes are direct quotes from the interview transcripts (see column one), while the second-order themes are the risk factors that represent the first-order codes (see 
column two). The third column indicates the presence or absence of evidence obtained from the interview cases. A tick $(\sqrt{ })$ represents the presence of evidence, whereas no tick represents no evidence (see column three). Finally, the aggregate dimensions reveal the main AFSC risk types (see column four).

\section{Insert Table 3}

Although a number of risk factors were identified in the literature (compared to Table 4), the empirical findings still revealed the existence of additional risk factors in the current AFSC practices. Examples of such risk factors include oral contract or agreement with partners, skill shortage, tax evasion, and the lack of investment in promoting agri-food products in the management and operational risk category, and the rapid technological development in the logistical and infrastructure risks category. It is interesting to note that no policy and regulatory risks were identified through the empirical study. This may be because all the interviewees were experienced people who have been working in the AFSC for many years; thus, misapplication of the systems or standards was unlikely.

\section{Insert Table 4}

\subsection{Risk hierarchy model built from TISM analysis}

The risk factors generated from the thematic analysis were used as inputs to process the TISM analysis to build a risk hierarchy model consisting of nine steps, as illustrated in Figure 3.

\section{Insert Figure 3}

1. Identification and definition of elements: Sixteen AFSC risk factors that were identified through a thematic analysis were used as inputs to process the TISM analysis. 2. Definition of contextual relationships: The contextual relationship between two AFSC risks is defined as "Risk A will influence/cause Risk B."

3. Interpretation of relationships: Eight experts involved in the semi-structured interviews were selected based on their nationality, working experience, job specialisation, and current management level, to obtain their opinions on whether the relationship "Risk A will influence/cause Risk B" actually exists or not (Yes or No). Janes (1988) suggested that it is essential for the participants to have the necessary technical knowledge.

4. Interpretive logic of the pair-wise comparison: An "interpretive logic-knowledge base" was developed for a pair-wise comparison of the 16 identified AFSC risks. There are in total 240 (i.e. $16 * 16-16=240$ ) rows in the knowledge base for implementing this study.

5. Reachability matrix and transitivity test: An initial reachability matrix of AFSC risks was developed from the interpretive logic-knowledge base by entering " 1 " for "Yes" and "0" for "No" (see Appendix B). Then, we checked the initial reachability matrix for transitivity rules and further converted it into a final reachability matrix (see 
Appendix C). The transitivity rules are that: if element " $A$ " relates to element " $\mathrm{B}$ " and element " $B$ " relates to element " $C$," then it is implied that element " $A$ " necessarily relates to element "C."

6. Level partitioning of the reachability matrix: The final reachability matrix obtained from the previous step was partitioned into different levels based on the reachability and antecedent sets for each element through a series of iterations (Singh and Sushil 2013). The level partitioning was performed until the levels of all AFSC risks were determined. The partitioning process of AFSC risks is illustrated in Appendix D. Lastly, the 16 AFSC risks were partitioned into nine levels (I to IX), as shown in Table 5. These determined levels were used to develop a digraph and a TISMbased hierarchy model.

\section{Insert Table 5}

7. Development of the digraph: For visualisation purposes, the 16 AFSC risks were depicted as a digraph in which direct links were drawn as per the relationships shown in the final reachability matrix, with dotted lines used to represent significant transitive links in the digraph.

8. Interpretive matrix: Through translating all interactions in the digraph by 1 in the respective cell, a binary interaction matrix was developed. The cells with a " 1 " entry were interpreted by selecting the appropriate interpretation from the knowledge-base in the form of an interpretive matrix (Jayalakshmi and Pramod 2015).

9. A total interpretive structural model of AFSC risks: The relevant and interpretive information from the interpretive matrix and digraph was used to develop the TISM hierarchy model of AFSC risks, as shown in Figure 4. The interpretation of each link was written on the line representing the respective links in the TISM hierarchy model.

The TISM analysis of AFSC risks resulted in a TISM model of nine levels. It can be observed that extreme weather conditions (E14), political and economic instability (E15), poor agricultural infrastructure (E12), pest and disease risk (E6), poor planning (E9), lack of information sharing among partners (E13), and supply and demand imbalance (E10) constitute levels four to nine in the TISM hierarchy model. Delay in payment (E1), bad debts (E2), and rapid technological development (E16) are at the third level followed by the lack of investment in promoting agri-food products (E7) and high energy costs (E8) which occupy the second level. Finally, market price fluctuations (E4), skill shortage (E3), tax evasion (E5), and oral contract or agreement with partners (E11) constitute the first level in the TISM hierarchy model. The TISM model demonstrates that extreme weather conditions and political and economic instability are the biggest threats to the AFSC, since they cause poor agricultural infrastructure. Poor infrastructure such as the lack of advanced information and communication technologies makes the AFSC practitioners reluctant to share information among partners. Thus, the lack of information sharing and its direct result of poor planning are common phenomena in AFSCs. Simultaneously, lack of long-term planning against pests and diseases makes agri-food products susceptible to them, resulting in less production and more investment in pest and disease research. Therefore, more projects will be conducted to facilitate technological development. It is important to note that pests and diseases drive up energy costs because more water and energy should be used to tackle this problem. Furthermore, poor planning aggravates the supply and demand imbalance. The drop in agri-food products' prices causes a reduction in the AFSC practitioners' income. Therefore, AFSC practitioners always experience delays in payments and even bad debts, thus lacking the money to organise training sessions for 
employees, avoiding paying labour taxes, and lacking investment in promoting agri-food products.

\section{Insert Figure 4}

The TISM hierarchy model of AFSC risks, which shows direct and transitive relationships between various identified risks factors, will improve the performance of AFSC by avoiding an increase in the level of some risks when other risks are mitigated.

\subsection{Fuzzy MICMAC analysis: classification of AFSC risks}

The TISM hierarchy model is developed by computing the relationships between two AFSC risks as " 0 " or " 1 ". If there is no relationship between two AFSC risks, then it is denoted by " 0 ", whereas if there is a relationship, then it is denoted by 1 . However, the relationships between these risks cannot always be equal. Some relations may be strong, some may be significantly strong, while other relations may be weak (Yadav and Barve 2016). To overcome the drawbacks of the TISM model, the fuzzy MICMAC analysis was used to assess the strength of relationships to increase the sensitivity of the analysis rather than for the mere evaluation of relationships so far. Regarding relationship strength, a higher driving power means a higher driver of the whole system, and a higher dependence power means a higher dependency on the whole system. The fuzzy MICMAC analysis was conducted in three steps.

\section{Step 1: The binary direct relationship matrix}

A binary direct reachability matrix was obtained by converting the diagonal entries into zeros and ignoring transitivity in the final reachability matrix of AFSC risks, as shown in Appendix E.

\section{Step 2: Development of the fuzzy direct relationship matrix}

The conventional MICMAC analysis considers only binary types of relationships, and therefore, to improve its sensitivity, the fuzzy set theory was applied. According to the fuzzy set theory, the possibility of interaction can be defined by a qualitative consideration on a $0-1$ scale (i.e. no: 0 , very low: 0.1 , low: 0.3 , medium: 0.5 , high: 0.7 , very high: 0.9 , and complete: 1). Using these values, the opinions of aforementioned experts in the TISM analysis were used to rate the relationship between two AFSC risks. Then, the values were superimposed on the binary direct reachability matrix to obtain a fuzzy direct reachability matrix, thus enhancing the research robustness, as it considers the reachability possibility instead of the simple consideration of reachability used so far. The fuzzy direct reachability matrix is shown in Appendix F.

\section{Step 3: Generation of fuzzy MICMAC stabilised matrix}

The principle of fuzzy matrix multiplication proposed by Kandasamy, Smarandache and IIanthenral (2007) was used as guidance for the multiplication process to obtain stabilisation. Fuzzy matrix multiplication is fundamentally a generalisation of the Boolean matrix multiplication. As per the fuzzy set theory, when two fuzzy matrices are multiplied, the outcome is also a fuzzy matrix. The matrix is multiplied repeatedly until the dependence and 
driving power are constant. Dependence and driving power were obtained by summing the entries of interactions' possibilities in the rows and columns separately. The rule of multiplication is shown as follows:

$$
\mathrm{C}=\mathrm{A}, \mathrm{B}=\max \mathrm{k}\left[\left(\min \left(\mathrm{a}_{\mathrm{ik}}, \mathrm{b}_{\mathrm{kj}}\right)\right] \text { where } \mathrm{A}=\left[\mathrm{a}_{\mathrm{ik}}\right] \text { and } \mathrm{B}=\left[\mathrm{b}_{\mathrm{kj}}\right]\right.
$$

Using MATLAB to calculate the matrices following the aforementioned rule, a stabilised matrix was obtained as shown in Table 6. Figure 5 presents the visualisation of the AFSC risk classification along two dimensions: dependence and driving power.

\section{Insert Table 6}

\section{Insert Figure 5}

As shown in Figure 5, the 16 AFSC risk factors identified from the thematic analysis are classified into four groups:

- Linkage variables group: Factors in this group have both high driving and dependence power. A high driving power has a significant effect on the system, whereas high dependence power is highly dependent on the system. There is only one risk factor in this group, which is bad debt (E2). Any change in this system will have an effect on this risk factor and feedback on itself. Although the lower level risks in the TISM hierarchy may induce or affect this risk, it also has a significant driving power to influence some other risks.

- Independent variables group: The risk factors are characterised by high driving and low dependence power, which include risks from pests and diseases (E6), poor planning (E9), supply and demand imbalance (E10), poor agricultural infrastructure (E12), lack of information sharing among partners (E13), extreme weather conditions (E14), political and economic instability (E15). These risks act as inputs and key variables of the system and lie at the bottom of the TISM hierarchy model, which can induce a series of other AFSC risks and have a severe impact on AFSC.

- Dependent variables group: The dependent variables are delay in payment (E1), skill shortage (E3), market price fluctuations (E4), tax evasion (E5), lack of investment in promoting agri-food products (E7), high energy costs (E8), and oral contract or agreement with partners (E11), which have high dependence and low driving power. These risks are highly dependent on the inputs of the system, which indicates that these risk factors require all the other risk factors to minimise the effect on AFSC.

- Autonomous variables group: Factors in this group have less driving and dependence power. There is only one risk factor in this group, which is the rapid technological development (E16). This risk factor is always disconnected from the system, with which it has only a few links in the TISM hierarchy model. Noticeably, it does not have much influence on the system.

\section{Discussion}

We used semi-structured interviews to collect data on AFSC risks from four countries over one year. Among the 16 AFSC risk factors identified through thematic analysis and shown in Table 4 , a minority of the determinants such as oral contract or agreement with partners, skill shortage, tax evasion, lack of investment in promoting agri-food products, and rapid technological 
development are new AFSC risk factors; however, there are several determinants that support the literature. Prakash et al. (2017) revealed that rapid technological development should be tackled as the second priority following by forecast error, but the findings of this current study show that rapid technological development does not have so much influence on the AFSC. This may be because most AFSC practitioners such as farmers are reluctant to use the latest technologies to share information, change the flavour, and improve the quality of agri-food products. Mostly, they rely on their experience rather than on technology to cultivate, prevent pests and diseases, and harvest. Howland et al. (2015) identified a lack of skilled workers who can share data and use information and communication technology (ICT), and this study confirms the result in the context of AFSC. Sharing information is critical for AFSC because it helps to reduce uncertainty in supply and demand, decrease inventory levels, increase food quality and safety, and reduce food wastage due to expiration (Ferguson and Ketzenberg. 2006; Kaipia, Dukovska-Popovska, and Loikkanen 2013). Our empirical findings indicate that it is extremely difficult to hire skilled workers to work in rural areas, despite providing proper salaries, permanent contracts, and proper training. We suggest that governments should introduce preferential policies for people who want to work in farms like the ones implemented by the EU to encourage people from Eastern Europe to work in France. Kleindl (2000) stated that the lack of investment is a common situation faced by small- and medium-sized companies, which is reinforced in this study. Additionally, experienced AFSC practitioners suggest that small farmers should cooperate to establish associations to tackle financial limitations, such as the Auction Market in southern France, the Association of Bolivian Farmers in Argentina, and the Association of Valencia farmers in Spain.

With the help of TISM and fuzzy MICMAC analyses (see Figures 4 and 5), we found that the biggest threats to the AFSC are political and weather-related risks, since the resulting dependencies might lead to logistical and infrastructure risk, and further induce or affect existing risks such as demand, financial, and management and operational risks. Peck (2005) illustrated that risks emanating from the political, economic, social, technological and natural environments with the highest driving power can affect the whole AFSC. For example, independent variables in this study such as extreme weather conditions and political and economic instability, which have the highest driving power and form the lowest level in the TISM hierarchy model, are considered as the key risks. The research conducted by Alesina et al. (1996) highlighted that political instability would cause low economic growth - even recession - and further induce a series of problems such as lack of investment in agricultural infrastructure. Thus, a focus on mitigating extreme weather conditions and political and economic instability will help to control other AFSC risks. Therefore, these risks should be tackled as a high priority. A comparison of present results with previous studies like the work done by Diabat, Govindan and Painicker (2012) on modelling the risks of food supply chain supports the results of this study to some degree by placing political and weather-related risks at the bottom of the TISM hierarchy. But, while the risks of the present study are in the independent variables group, they are classified under the linkage variables group in earlier works. This contrast shows that the current AFSCs of Argentina, France, Spain and Italy are experiencing more threats from the political and weather-related risks; for example, Argentina experienced four political and economic changes from 1989 to 2016 which had a significant impact on the local AFSC. Market price fluctuations, skill shortage, tax evasion, and oral contract or agreement with partners are the dependent risks and have relatively high dependence power, thus forming the top level in the TISM hierarchy model. These risks are greatly affected by many other risks. However, market price fluctuations is placed in the linkage variables group in previous studies (Diabat et al. 2012). This difference is because market price fluctuations identified in the present study is affected by many other risks and their relative significance and interdependencies also differ from those reported in other studies. 


\section{Contributions}

This study investigates the AFSC risks from theoretical and empirical perspectives. A combination of multiple qualitative research methods was applied in this research, providing guidance for researchers on examining driver-dependent relationships among AFSC risks using semi-structured interviews, thematic analysis, TISM, and fuzzy MICMAC analysis. The key findings of this study contribute to the existing body of knowledge while answering the three aforementioned research questions: (1) it provides empirical evidence of the main risks that can make the AFSC vulnerable. Although many studies (e.g., Wagner and Bode. 2006; Tang and Tomlin. 2008; Esteso et al. 2018) have analysed the risk factors in the supply chain context from an empirical perspective, this study identified five new risk factors; these are oral contract or agreement with partners, skill shortage, lack of investment in promoting agri-food products, tax evasion, and rapid technological development. We extend existing studies that primarily focus on supply chain risk identification. Although we cannot eliminate political and economic instability and extreme weather conditions, an active supply chain risk identification is very necessary (Quang and Hara 2018). A superior risk identification supports the subsequent risk assessment and this in turn leads to better risk mitigation (Aqlan and Lam 2015). (2) It develops a TISM hierarchy model of AFSC risks, which can help us to understand interrelationships among different types of AFSC risks. The interdependencies and interrelationships among various risk types in literature are currently inadequate (Ho et al. 2015), which confirms the emerging need for this research. Previous studies (Pfohl et al. 2011; Diabat, Godindan, and Painicker 2012; Bier, Lange, and Glock 2019) only used ISM to identify interrelationships between different risk factors in the supply chain context, with no study using the TISM method to develop an AFSC model that considers the interrelationships among different AFSC risk factors. To the best of our knowledge, this is the first study to define the interrelationships among different AFSC risks using TISM. Furthermore, the proposed TISM hierarchy model identified 16 risk factors at nine different layers and highlights their specific roles. (3) Finally, it identifies the key risks in AFSC using the fuzzy MICMAC analysis. By categorising various risks into different categories based on the experts' opinions in a structured and systematic way, key risk types that drive the system are identified. This answers the call to strengthen the research in the supply chain risk classification as research on this topic is still in its infancy (Sodhi, Son, and Tang 2012; Rangel et al. 2015).

This study contributes significantly to the managerial practices. First, it identifies various types of risk from the AFSC perspective, which gives practitioners a general overview of AFSC risks and increases their risk awareness. A survey conducted by the Economist (2009) indicated that more than one-third of respondents hold the view that there is a lack of understanding of supply chain risk at the broad level and almost half of the respondents believe their company under-estimates the potential impact of supply chain risk. The results of this empirical study will help AFSC managers to build awareness of possible risks that the AFSC faces and enable them to take necessary actions in advance to prevent the risk or mitigate the risk effects. Second, it investigates interrelationships among different types of AFSC risks. Investigating the joint impact of various risks can lead to better management of AFSC than tackling each risk factor in isolation (Ho et al. 2015). A more comprehensive understanding of the AFSC risks and their interrelationships, through a logical structure, will enable AFSC managers to prioritise and allocate the resources in an effective way. Thus, AFSC managers can focus on the key risks (extreme weather conditions and political and economic instability) that cause vulnerabilities within the AFSC. This will reduce the time and effort required to mitigate the effects of risks if the key risk is targeted initially. To mitigate the effect of extreme weather conditions, it is suggested that the large agri-food companies take out weather damage and business insurance, whereas it is suggested that the small- and medium-sized companies 
apply for disaster relief emergency funding if the agricultural infrastructure is destroyed by extreme weather events. A possible method to alleviate the effect of political and economic instability is to strengthen the partnership with the suppliers and relationships with local government and non-profit organisations. Third, it classifies different risks into different categories of variables such as linkage, independent, dependent, and autonomous. This classification also helps AFSC managers differentiate between risks and their mutual relationships and formulate strategies to mitigate the effects of independent risks while developing contingency plans for linkage risks, and to monitor the dependent risks. However, alleviating the effects of dependent risks will not help mitigate any of the other risks because dependent risks are at the top of the TISM hierarchy model. Furthermore, our classification can be used to explain, communicate, and transfer risk knowledge between different departments of the company, as well as between various partners within the AFSC, thus enabling an effective management that deals with the various risk types from both the company and overall supply chain perspectives.

\section{Conclusion and future research directions}

At present, it is important for researchers and practitioners to have a deep understanding and knowledge of interrelationships among different AFSC risks. To attain this objective and manage AFSC risks appropriately, 16 in-depth semi-structured interviews with experienced AFSC practitioners were conducted in four different countries. Then, 16 AFSC risk factors were identified through thematic analysis. After that, we applied TISM to uncover the potential interrelationships among the identified risk factors. Finally, we used the fuzzy MICMAC analysis to identify the key risks in various categories. The results indicate that political and weather-related risks have the highest driving power and lie at the lowest level of the TISM hierarchy; thus, they should be given top priority.

Nevertheless, this study does have some limitations. First, no prevention strategies are proposed to mitigate the risks discussed. Second, the empirical study was conducted in a limited number of countries (i.e. Spain, France, Italy and Argentina). Therefore, when the results are applied to other contexts, country-specific factors such as cultural impacts on supply chain risks should be taken into consideration. Third, only qualitative research methods have been applied. Fourth, the driving direction (positively/negatively influence) between different AFSC risks has not been investigated using TISM. These limitations open avenues for further research as follows:

(1) Resilience capabilities/strategies should be developed to help all AFSC companies to mitigate the risks. This is because all the companies in the AFSC will need some strategies to recover from risks.

(2) The study results should be applied to other countries to check their general validity. Additionally, an international survey would provide further insights concerning the AFSC risks in other countries or could identify cultural differences concerning AFSC risks.

(3) Implementing a hybrid (combination of qualitative and quantitative) technique could improve AFSC risks analysis in further research. Hussein (2015) showed that the use of both qualitative and quantitative methods in studying the same phenomenon has positive effects on improving the accuracy and deeper understanding of the study. Thus, structural equation modelling (SEM) can be applied in future research.

(4) The driving direction (positively/negatively influence) should be incorporated into TISM in the step of defining the contextual relationships and interpretation of relationships. If there is a relationship between two elements, then its driving direction also needs to be specified. Furthermore, experts' explanations that element A will positively/negatively influence element 
B should be clarified. Sushil (2018) has provided Systematic guidance for considering the polarity of relationships in TISM. 


\section{References}

Ahumada, O., and J.R. Villalobos. 2009. "Application of planning models in the agri-food supply chain: A review.” European Journal of Operational Research 195: 1-20.

Alesina, A., S. Ozler, N. Roubini, and P. Swagel. 1996. "Political instability and economic growth." Journal of Economic Growth 1: 189-211.

Amma, T.A., N, Radhika, and V.R. Pramod. 2014. "Modelling structural behaviour of inhibitors of cloud computing: A TISM approach." Transactions on Networks and Communications 2 (5): 60-74.

Anton, J., S, Kimura, and R. Martini. 2011. "Risk Management in Agriculture in Canada." OECD Food, Agriculture and Fisheries Papers, 40. OECD Publishing: Paris.

Aqlan, F., and S.S. Lam. 2015. "Supply chain risk modelling and mitigation." International Journal of Production Research 53 (18): 5640-5656.

Bachev, H. 2017. "Supply chain risk management - Agri-food implications." Noble International Journal of Business and Management Research 1 (1): 10-30.

Baghalian, A., S. Rezapour, and R.Z. Farahani. 2013. "Robust supply chain network design with service level against disruptions and demand uncertainties: A real-life case." European Journal of Operational Research 227: 199-215.

Barriball, K.L., and A, While. 1994. "Collecting data using a semi-structured interview: a discussion paper." Journal of Advanced Nursing 19: 328-335.

Baryannis, G., S. Validi, S. Dani, and G. Antoniou. 2019. "Supply chain risk management and artificial intelligence: state of the art and future research directions." International Journal of Production Research 57 (9): 2179-2202.

Behzadi, G., M.J. O’Sullivan, T.L. Olsen, and A. Zhang. 2018. "Agribusiness supply chain risk management: A review of quantitative decision models." Omega 79: 21-42.

Bhosale, V.A., and R. Kant. 2016. "An integrated ISM fuzzy MICMAC approach for modelling the supply chain knowledge flow enablers." International Journal of Production Research 54 (24): 7374-7399.

Bier, T., A. Lange, and C.H. Glock. 2019. "Methods for mitigating disruptions in complex supply chain structures: a systematic literature review." International Journal of Production Research, DOI: 10.1080/00207543.2019.1687954.

Blackhurst, J., C.W. Craighead, D. Elkins, and R.B. Handfield. 2005. “An empirically derived agenda of critical research issues for managing supply-chain disruptions." International Journal of Production Research 43 (19): 4067-4081.

Bogataj, D., and M. Bogataj. 2007. "Measuring the supply chain risk and vulnerability in frequency space.” International Journal of Production Economics 108 (1-2): 291-301.

Bondy, J.A., and U.S.R. Murty. 1976. "Graph theory with applications." Elsevier Science Publishing: New York.

Borodin, V., J. Bourtembourg, F. Hnaien, and N. Labadie. 2016. "Handling uncertainty in agricultural supply chain management: A state of the art." European Journal of Operational Research 234: 348-359.

Braun, V., and V. Clarke. 2006. "Using thematic analysis in psychology." Qualitative Research in Psychology 3 (2): 77-101. 
Cavinato, J.L. 2004. "Supply chain logistics risks: From the back room to the board room." International Journal of Physical Distribution \&Logistics Management 34 (5): 383-387.

Chan, F.T.S., and N. Kumar. 2007. "Global supplier development considering risk factors using fuzzy extended AHP-based approach." Omega 35: 417-431.

Chopra, S., and M.S. Sodhi. 2004. "Managing risk to avoid supply-chain breakdown." MIT Sloan Management Review 46 (1): 53-61.

Christopher, M., and H. Peck. 2004. "Building the resilient supply chain." The International Journal of Logistics Management 15 (2): 1-14

Christopher, M., C. Mena, and O. Yurt. 2011. "Approaches to managing global sourcing risk." Supply Chain Management: An International Journal 16: 67-81.

Clarke, N.J., M.E.H. Willis., J.S. Barnes., N. Caddick., J. Cromby., H. McDermott., and G. Wiltshire. 2015. "Analytical pluralism in qualitative research: a meta-study." Qualitative Research in Psychology 12 (2): 182-201.

Cohen, J. 1960. "A coefficient of agreement for nominal scales." Educational and Psychological Measurement 20 (1): 37-46.

Corbin, J., and A. Strauss. 2014. "Basics of qualitative research: techniques and procedures for developing grounded theory, 4th ed." Sage Publications Inc: USA.

Creswell, J.W. 2014. "Research design, qualitative, quantitative, and mixed methods approaches, 4th ed." Sage: London.

Dani, S., and A. Deep. 2010. "Fragile food supply chains: reacting to risks." International Journal of Logistics: Research and Applications 13 (5): 395-410.

Dani, S. 2015. "Food supply chain management and logistics: from farm to fork." Kogan Page Limited: London.

Diabat, A., K. Govindan, and V.V. Panicker. 2012. "Supply chain risk management and its mitigation in a food industry." International Journal of Production Research 50 (11): 30393050 .

Dicicco-Bloom, B., and B.F. Crabtree. 2006. "The qualitative research interview." Medical Education 40: 314-321.

Dowty, R.A., and W.A. Wallace. 2010. "Implications of organizational culture for supply chain disruption and restoration." International Journal of Production Economics 126: 57-65.

Economist. 2009. Managing supply-chain risk for reward. Technical Report, Economist Intelligence Unit.

Ellis, S.C., R. M. Henry, and J. Shockley. 2010. "Buyer perceptions of supply disruption risk: A behavioural view and empirical assessment." Journal of Operations Management 28 (1): 3446.

Esteso, A., M.M.E. Alemany, and A. Ortiz. 2018. "Conceptual framework for designing agrifood supply chains under uncertainty by mathematical programming models." International Journal of Production Research 56 (13): 4418-4446.

European Commission. 2018. "Statistical factsheet." Available at: https://ec.europa.eu/agriculture/sites/agriculture/files/statistics/factsheets/pdf/eu_en.pdf [Accessed: 21/06/2019]. 
Ferguson, M.E., and M.E. Ketzenberg. 2006. "Information sharing to improve retail product freshness of perishables." Production and Operations Management 15 (1): 57-73.

Food and Agriculture Organization. 2018. "Energy: Agri-food chains." Available at: http://www.fao.org/energy/agrifood-chains/en/ [Accessed: 05/12/2018].

Francis, J.J., M. Johnston, C. Robertson, L. Glidewell, V. Entwistle, M.P. Eccles, and J.M. Grimshaw. 2010. "What is an adequate sample size? Operationalising data saturation for theory-based interview studies." Psychology and Health 25 (10): 1229-1245.

Frost, N.A., A. Holt, P. Shinebourne, C. Esin, S-M. Nolas, L. Mehdizadeh, and B. BrooksGordon. 2011. "Collective findings, individual interpretations: an illustration of a pluralistic approach to qualitative data analysis." Qualitative Research in Psychology 8 (1): 93-113.

Ge, H., J. Nolan, R. Gray, S. Goetz, and Y. Han. 2016. "Supply chain complexity and risk mitigation - A hybrid optimization - simulation model." International Journal of Production Economics 79: 228-238.

Guan, G., Q. Dong, and C. Li. 2011. "Risk identification and evaluation research on F-AHP evaluation based supply chain." IEEE $18^{\text {th }}$ International Conference on Industrial Engineering and Engineering Management, Changchun: China, September 3-5.

Howland, F., L.A. Munoz, S. Staiger-Rivas, J. Cock, and S. Alvarez. 2015. "Data sharing and use of ICTs in agriculture: working with small farmer groups in Colombia." Knowledge Management for Development Journal 11 (2), pp. 44-63.

Ho, W., T. Zheng, H. Yildiz, and S. Talluri. 2015. "Supply chain risk management: a literature review." International Journal of Production Research 53 (16): 5031-5069.

Hussein, A. 2015. "The use of triangulation in social sciences research: Can qualitative and quantitative methods be combined?" Journal of Comparative Social Work 4 (1): 1-12.

Jaffee, S., P. Siegel, and C. Andrews. 2010. Rapid agriculture supply chain risk assessment: A conceptual framework. Washington: The World Bank.

Jain, V., and T. Raj. 2015. "Modelling and analysis of FMS flexibility factors by TISM and fuzzy MICMAC." International Journal of System Assurance Engineering and Management 6 (3): 350-371.

Janes, F.R. 1988. "Interpretive structural modelling: a methodology for structuring complex issue." Transactions of the Institute of Measurement and Control 10 (3): 145-154.

Javadi, M., and K. Zarea. 2016. "Understanding thematic analysis and its pitfall." Journal of Client Care 1 (1): 34-40.

Jayalakshmi, B., and V.R Pramod. 2015. "Total interpretive structural modelling (TISM) of the enablers of a flexible control system for industry." Global Journal of Flexible Systems Management 16 (1): 63-85.

Jena, J., S. Sidharth, L.S. Thakur, D.K. Pathak, and V.C. Pandey. 2017. "Total interpretive structural modelling: approach and application." Journal of Advances in Management Research 14 (2): 162-181.

Jena, J., V. Fulzele, R. Gupta, F. Sherwani, R. Shankar, and S. Sidharth. 2016. "A TISM modelling of critical success factors of smartphone manufacturing ecosystem in India." Journal of Advances in Management Research 13 (2): 203-224. 
Juttner, U., H. Peck, and M. Christopher. 2003. "Supply chain risk management: outlining an agenda for future research." International Journal of Logistics: Research and Applications 6 (4): 197-210.

Kaipia, R., I. Dukovska-Popovska, and L. Loikkanen. 2013. "Creating sustainable fresh food supply chains through waste reduction." International Journal of Physical Distribution \& Logistics Management 43 (3): 262-276.

Kandasamy, W.B.V., F. Smarandache, and K. IIanthenral. 2007. Elementary fuzzy matrix theory and fuzzy models for social scientists. Automaton: Los Angeles.

King, N., and C. Horrocks. 2010. Interviews in qualitative research. Sage Publications: London.

Kleindl, B. 2000. "Competitive dynamics and new business models for SMEs in the virtual market place." Journal of Developmental Entrepreneurship 5 (1): 73-85.

Kleindorfer, P.R., and G.H. Saad. 2005. "Managing disruption risks in supply chains." Production and Operations Management 14 (1): 53-68.

KPMG. 2013. The agricultural and food value chain: entering a new era of cooperation. Available at: https://assets.kpmg.com/content/dam/kpmg/pdf/2013/06/agricultural-and-foodvalue-chain-v2.pdf [Assessed: 06/12/2018].

Kumar, S.K., M.K. Tiwari, and R.F. Babiceanu. 2010. "Minimisation of supply chain cost with embedded risk using computational intelligence approaches." International Journal of Production Research 48 (13): 3717-3739.

Laeequddin, M., G.D. Sardana, B.S. Sahay, K.A. Waheed, and V. Sahay. 2009. "Supply chain partners' trust building process through risk evaluation: the perspectives of UAE packaged food industry." Supply Chain Management: An International Journal 14 (4): 280-290.

Leat, P., and C. Revoredo-Giha. 2013. "Risk and resilience in agri-food supply chains: the case of the ASDA PorkLink supply chain in Scotland." Supply Chain Management: An International Journal 18 (2): 219-231.

Lin, Y., and L. Zhou. 2011. "The impacts of product design changes on supply chain risk: A case study." International Journal of Physical Distribution \& Logistics Management 41: 162186.

Macdonald, J.R., C.W. Zobel, S.A. Melnyk, and S.E. Griffis. 2018. "Supply chain risk and resilience: theory building through structured experiments and simulation." International Journal of Production Research 56 (12): 4337-4355.

Mangla, S.K., S. Luthra, N. Rich, D. Kumar, N.P. Rana, and Y.K. Dwivedi. 2018. "Enablers to implement sustainable initiatives in agri-food supply chains." International Journal of Production Economics 203: 379-393.

Marucheck, A., N. Greis, C. Mena, and L. Cai. 2011. "Product safety and security in the global supply chain: issues, challenges and research opportunities." Journal of Operations Management 29 (7-8): 707-720.

Mason, J.R., and D.R. Towill. 1998. "Shrinking the supply chain uncertainty cycle." IOM Control 27 (4): 17-22.

Micheli, G.J.L., R. Mogre, and A. Perego. 2014. "How to choose mitigation measures for supply chain risks." International Journal of Production Research 52 (1): 117-129. 
Moazzam, M., P. Akhtar, E. Garnevska, and N.E. Marr. 2018. "Measuring agri-food supply chain performance and risk through a new analytical framework: a case study of New Zealand dairy." Production Planning \& Control 29 (15): 1258-1274.

Morehouse, R. 2011. "Beginning interpretive inquiry: a step-by-step approach to research and evaluation." Routledge: USA.

Nakandala, D., H. Lau, and L. Zhao. 2017. "Development of a hybrid fresh food supply chain risks assessment model.” International Journal of Production Research 55 (14): 4180-4195.

Nyamah, E.Y., Y. Jiang, Y. Feng, and E. Enchill. 2017. “Agri-food supply chain performance: an empirical impact of risk." Management Decision 55 (5): 872-891.

O’Keeffe, J., W. Buytaert, A. Mijic, N. Brozovic, and R. Sinha. 2016. "The use of semistructured interviews for the characterisation of farmer irrigation practices." Hydrology and Earth System Sciences 20: 1911-1924.

Peck, H. 2005. "Drivers of supply chain vulnerability: an integrated framework." International Journal of Physical Distribution \& Logistics Management 35 (4): 210-232.

Pfohl, H-C., P. Gallus, and D. Thomas. 2011. "Interpretive structural modelling of supply chain risks." International Journal of Physical Distribution \& Logistics Management 41 (9): 839859.

Prakash, S., G. Soni, A.P.S. Rathore, and S. Singh. 2017. "Risk analysis and mitigation for perishable food supply chain: a case of dairy industry." Benchmarking: An International Journal 24 (1): 2-23.

Pujawan, I.N., and L.H. Geraldin. 2009. "House of risk: A model for proactive supply chain risk management.” Business Process Management Journal 15: 953-967.

Quang, H.T., and Y. Hara. 2018. "Risks and performance in supply chain: the push effect." International Journal of Production Research 56 (4): 1369-1388.

Rangel, D.A., T.K. Oliveira, and M.S.A. Leite. 2015. "Supply chain risk classification: discussion and proposal." International Journal of Production Research 53 (22): 6868-6887.

Rao, S., and T.J. Goldsby. 2009. "Supply chain risks: A review and typology." The International Journal of Logistics Management 20 (1): 97-123.

Regunaga, M., and A. Tejeda Rodriguez. 2015. Argentina's agricultural trade policy and sustainable development. Geneva: International Centre for Trade and Sustainable Development.

Ren, X-Y., Q-Q. Feng, S. Wang, and X. Wen. 2015. "Profit distribution of agricultural supply chain based on Shapley value." Advance Journal of Food Science and Technology 7: 479-483.

Ritchie, B., and C. Brindley. 2007. "An emergent framework for supply chain risk management and performance measurement." Journal of the Operations Research Society 58: 1398-1411.

Sandbhor, S., and R. Botre. 2014. "Applying total interpretive structural modelling to study factors affecting construction labour productivity." Australasian Journal of Construction Economics and Building 14 (1): 20-31.

Saunders, M.N.K., P. Lewis, and A. Thornhill. 2015. Research Methods for Business Students. Essex: Pearson Education.

Septiani, W., Marimin, Y. Herdiyeni, and L. Haditjaroko. 2016. "Method and approach mapping for agri-food supply chain risk management: A literature review." International Journal of Supply Chain Management 5 (2): 51-64. 
Si, S-L., X-Y. You, H-C. Liu, and P. Zhang. 2018. "DEMATEL technique: a systematic review of the state-of-the-art literature on methodologies and applications." Mathematical Problems in Engineering, DOI: https://doi.org/10.1155/2018/3696457.

Siddh, M.M., G. Soni, R. Jain, M.K. Sharma, and V. Yadav. 2017. "Agri-fresh food supply chain quality (AFSCQ): A literature review.” Industrial Management \& Data Systems 117 (9): 2015-2044.

Silverman, D. 2000. "Doing qualitative research: A practical handbook." Thousand Oaks, London, Sage: New Delhi.

Singh, A.K., and Sushil. 2013. "Modelling enablers of TQM to improve airline performance." International Journal of Productivity and Performance Management 62 (3): 250-275.

Sodhi, M.S. 2005. "Managing demand risk in tactical supply chain planning for a global consumer electronics company." Production and Operations Management 14 (1): 69-79. Sodhi, M.S., B.G. Son, and C.S. Tang. 2012. "Researchers' perspectives on supply chain risk management." Production and Operations Management 21 (1): 1-13.

Sushil. 2018. "Incorporating polarity of relationships in ISM and TISM for theory building in information and organization management." International Journal of Information Management 43: 38-51.

Tang, C., and B. Tomlin. 2008. "The power of flexibility for mitigating supply chain risks." International Journal of Production Economics 116 (1): 12-27.

Vaismoradi, M., H. Turunen, and T. Bondas. 2013. "Content analysis and thematic analysis: Implications for conducting a qualitative descriptive study." Nursing \& Health Sciences 15: 398-405.

Vanalle, R.M., W.C. Lucato, G.M.D. Ganga, and A.G.A. Filho. 2019. "Risk management in the automotive supply chain: An exploratory study in Brazil." International Journal of Production Research, DOI: 10.1080/00207543.2019.1600762.

Wagner, S.M., and C. Bode. 2006. "An empirical investigation into supply chain vulnerability." Journal of Purchasing and Supply Management 12 (6): 301-312Wagner, S.M., and C. Bode. 2008. "An empirical examination of supply chain performance along several dimensions of risk." Journal of Business Logistics 29: 307-325.

Weintraub, A., and C. Romero. 2006. "Operations research models and the management of agricultural and forestry resources: A review and comparison." Interfaces 36 (5): 446-457.

Wellington, J., and M. Szczerbinski. 2007. "Research methods for the social sciences." Continuuml: London.

Willis, J.W. 2007. "Foundations of qualitative research: interpretive and critical approaches." Sage: London.

Yadav, D.K., and A. Barve. 2016. "Modelling post-disaster challenges of humanitarian supply chains: A TISM approach." Global Journal of Flexible Systems Management 17 (3): 321-340.

Yadav, G., and T.N. Desai. 2017. "Analyzing lean six sigma enablers: a hybrid ISM-fuzzy MICMAC approach.” The TQM Journal 29 (3): 488-511.

Yadav, N., and Sushil. 2014. "Total interpretive structural modelling (TISM) of strategic performance management for Indian telecom service providers." International Journal of Productivity and Performance Management 63 (4): 421-445. 
Yang, B., and Y. Yang. 2010. "Postponement in supply chain risk management: a complexity perspective.” International Journal of Production Research 48 (7): 1901-1912.

Yeboah, N.E., Y. Feng, O-S. Daniel, and N.B. Joseph. 2014. "Agricultural supply chain risk identification - A case finding from Ghana." Journal of Management and Strategy 5 (2): 3148.

Zhang, K., Y. Chai, S.X. Yang, and D. Weng. 2011. "Pre-warning analysis and application in traceability systems for food production supply chains." Expert Systems with Applications 38: 2500-2507.

Zhou, L., G. Zhou, F. Qi, and H. Li. 2019. "Research on coordination mechanism for fresh agri-food supply chain with option contracts." Kybernetes 48 (5): 1134-1156.

Zsidisin, G.A. 2003. "A grounded definition of supply risk." Journal of Purchasing \& Supply Management 9 (5-6): 217-224. 


\section{TABLES}

Table 1 Typical research methods for AFSC risks

\begin{tabular}{|c|c|c|c|c|}
\hline Author(s) (year) & Topic focus & Research methods & $\begin{array}{l}\text { Theoretical/ } \\
\text { empirical }\end{array}$ & $\begin{array}{l}\text { Qualitative/ } \\
\text { quantitative }\end{array}$ \\
\hline Ritchie and Brindley (2007) & Risk mitigation & Case study & Empirical & Qualitative \\
\hline Wagner and Bode (2008) & Risk identification and analysis & $\begin{array}{l}\text { Ordinary least square } \\
\text { regression model }\end{array}$ & Empirical & Quantitative \\
\hline Laeequddin et al. (2009) & Risk assessment & $\begin{array}{l}\text { Multiple regression } \\
\text { model }\end{array}$ & Theoretical & Quantitative \\
\hline $\begin{array}{l}\text { Pujawan and Geraldin } \\
\text { (2009) }\end{array}$ & Risk assessment and mitigation & $\begin{array}{l}\text { Failure mode and effect } \\
\text { analysis }\end{array}$ & Theoretical & Quantitative \\
\hline Dani and Deep (2010) & Risk mitigation & Case study & Theoretical & Qualitative \\
\hline Dowty and Wallace (2010) & Contingency planning & Case study & Empirical & Qualitative \\
\hline Christopher et al. (2011) & Risk analysis and mitigation & Case study & Empirical & Qualitative \\
\hline Guan et al. (2011) & Risk identification & $\begin{array}{l}\text { Analytic hierarchy } \\
\text { process }\end{array}$ & Theoretical & Quantitative \\
\hline Zhang et al. (2011) & Contingency planning & Simulation & Theoretical & Quantitative \\
\hline Diabat et al. (2012) & Risk assessment & $\begin{array}{l}\text { Interpretive structural } \\
\text { modelling and case } \\
\text { study }\end{array}$ & Empirical & Qualitative \\
\hline $\begin{array}{l}\text { Baghalian, Rezapour, and } \\
\text { Farahani (2013) }\end{array}$ & Risk analysis & $\begin{array}{l}\text { Integer nonlinear } \\
\text { programming }\end{array}$ & Theoretical & Quantitative \\
\hline $\begin{array}{l}\text { Leat and Revoredo-Giha } \\
\text { (2013) }\end{array}$ & $\begin{array}{l}\text { Risk identification and } \\
\text { contingency planning }\end{array}$ & Case study & Empirical & Qualitative \\
\hline Ren et al. (2015) & Risk assessment & Shapley value method & Theoretical & Quantitative \\
\hline Septiani et al. (2016) & $\begin{array}{l}\text { Risk identification, assessment } \\
\text { and mitigation }\end{array}$ & Literature review & Theoretical & Qualitative \\
\hline Behzadi et al. (2018) & Risk mitigation & Literature review & Theoretical & Qualitative \\
\hline Esteso et al. (2018) & Risk mitigation & Literature review & Theoretical & Qualitative \\
\hline Moazzam et al. (2018) & Risk assessment & Case study & Empirical & Qualitative \\
\hline Zhou et al. (2019) & Risk mitigation & Case study & Empirical & Qualitative \\
\hline
\end{tabular}


Table 2 Detailed information of the interviews

\begin{tabular}{|c|c|c|c|}
\hline Country & Company & $\begin{array}{l}\text { Interviewees' } \\
\text { position }\end{array}$ & Role and responsibility in AFSC \\
\hline \multirow{4}{*}{ Spain } & $\mathrm{A}$ & $\begin{array}{l}\text { Project } \\
\text { manager }\end{array}$ & $\begin{array}{l}\text { Input supplier: (1) Advising on research and development of agri-food; (2) } \\
\text { Transferring the scientific results obtained and maintaining relations with the } \\
\text { agri-food sector. }\end{array}$ \\
\hline & $\mathrm{B}$ & Director & $\begin{array}{l}\text { Cooperative: (1) Fully involved in aspects of food safety and quality, } \\
\text { guaranteeing in all cases compliance with the established legal requirements } \\
\text { and thus securing food at the level of safety demanded by both the market } \\
\text { and consumers. }\end{array}$ \\
\hline & $\mathrm{C}$ & Co-owner & $\begin{array}{l}\text { Food processor, wholesaler, and distributor: (1) Suppliers of major } \\
\text { national and international supermarkets; }\end{array}$ \\
\hline & $\mathrm{D}$ & Director & $\begin{array}{l}\text { Retailer: (1) Requiring the participation of professionals in agriculture } \\
\text { through implementing agricultural policy; (2) Securing the farmers' interest } \\
\text { and promoting their profitability. }\end{array}$ \\
\hline \multirow{5}{*}{ France } & $\mathrm{A}$ & $\begin{array}{l}\text { Marketing } \\
\text { manager }\end{array}$ & $\begin{array}{l}\text { Input supplier: (1) Developing new varieties of vegetables; mainly } \\
\text { cauliflower, artichokes, shallots and onions. }\end{array}$ \\
\hline & $\mathrm{B}$ & $\begin{array}{l}\text { Operation } \\
\text { director }\end{array}$ & $\begin{array}{l}\text { Input supplier: (1) Specialising in agricultural equipment and management } \\
\text { of rural areas through collaborating with professional agricultural } \\
\text { organisations and thousands of cooperatives. }\end{array}$ \\
\hline & $\mathrm{C}$ & Director & $\begin{array}{l}\text { Farmers: (1) Cultivating plants to generate a weaker consumption of inputs } \\
\text { and impacts more in favour of biodiversity, health and environment; (2) } \\
\text { Cultivating different plants to improve the business cluster competitiveness. }\end{array}$ \\
\hline & $\mathrm{D}$ & Director & Cooperatives: (1) Formulating region-specific agriculture policies. \\
\hline & $\mathrm{E}$ & Director & $\begin{array}{l}\text { Food processor, wholesaler, and distributor: (1) Supporting shippers and } \\
\text { distributors; (2) Monitoring consumer trends; (3) Developing packaging } \\
\text { formats and innovative solutions in response to the network demand. }\end{array}$ \\
\hline \multirow[t]{2}{*}{ Italy } & $\mathrm{A}$ & $\begin{array}{l}\text { Project } \\
\text { manager }\end{array}$ & $\begin{array}{l}\text { Cooperatives: (1) Providing information and training opportunities for } \\
\text { farmers and agri-food companies; (2) Dissemination of good agricultural } \\
\text { practices. }\end{array}$ \\
\hline & B & $\begin{array}{l}\text { Operation } \\
\text { manager }\end{array}$ & $\begin{array}{l}\text { Food processor: (1) Building direct relationships with local farmers and } \\
\text { doing business in the field of vegetable extracts. }\end{array}$ \\
\hline \multirow{5}{*}{ Argentina } & $\mathrm{A}$ & Co-owner & $\begin{array}{l}\text { Input supplier: (1) Mainly responsible for selling agri-chemical and various } \\
\text { types of seeds to farmers. }\end{array}$ \\
\hline & B & Director & $\begin{array}{l}\text { Input supplier: (1) Mainly responsible for transferring agricultural } \\
\text { knowledge to farmers. }\end{array}$ \\
\hline & $\mathrm{C}$ & Owner & $\begin{array}{l}\text { Farmers: (1) Mainly responsible for producing different kinds of vegetables } \\
\text { such as tomatoes, eggplants and cucumbers. }\end{array}$ \\
\hline & $\mathrm{D}$ & Director & $\begin{array}{l}\text { Cooperative: (1) Disseminating good agricultural practices and providing } \\
\text { quality certificates to farmers; (2) Providing training courses for farmers, } \\
\text { especially for smallholders. }\end{array}$ \\
\hline & $\mathrm{E}$ & Director & $\begin{array}{l}\text { Wholesaler, distributor, and retailer: (1) A platform for farmers to sell } \\
\text { their products in this market; } 20 \% \text { of vegetables and fruits production in } \\
\text { Argentina are sold there. }\end{array}$ \\
\hline
\end{tabular}




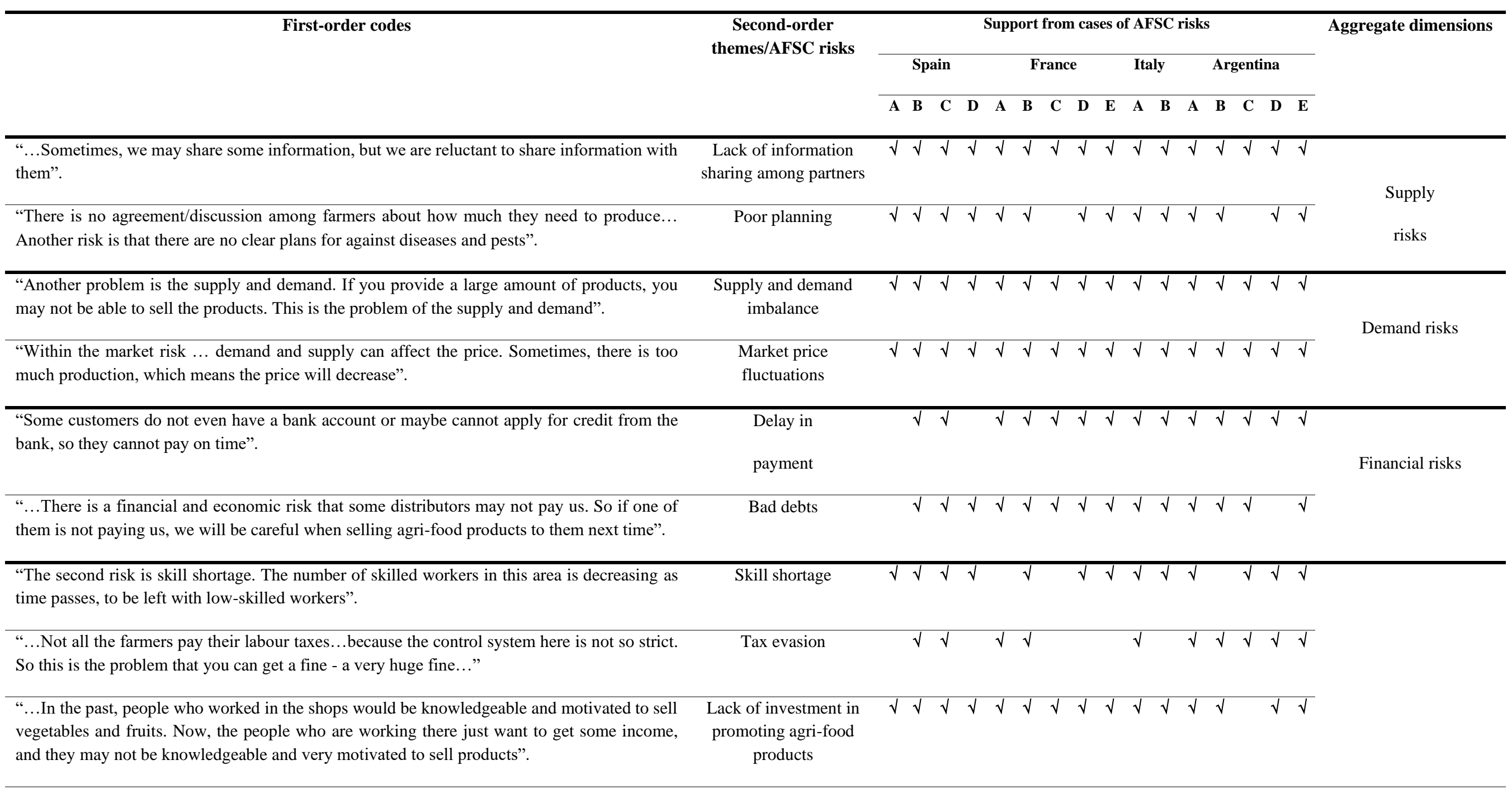


“...They negotiate with each other on how much each family should pay for renting the land.

Oral contract or

$\sqrt{ } \sqrt{ } \quad \sqrt{ }$

$\begin{array}{lllllll}\sqrt{ } & \sqrt{ } & \sqrt{ } & \sqrt{ } & \sqrt{ } & \sqrt{ } & \sqrt{ }\end{array}$

Management and

There is no paper work of the agreement since they do not need to sign an agreement to say that agreement with partners

operational risks

you are going to pay this and you are going to pay that".

"The most important thing is to know is that there were four political and economic changes

Political and economic

$\sqrt{ } \sqrt{ }$

instability

Political and

from 1989 to 2016 which had an impact on the agriculture value chain".

$\begin{array}{lllllllllllllllll}\text { High energy } & \sqrt{ } & \sqrt{ } & \sqrt{ } & \sqrt{ } & \sqrt{ } & \sqrt{ } & \sqrt{ } & \sqrt{ } & \sqrt{ } & \sqrt{ } & \sqrt{ } & \sqrt{ } & \sqrt{ } & \sqrt{ } & \sqrt{ } & \sqrt{ }\end{array}$

costs

underground, so it is free. It is quite a lot of electricity fee -3000 dollars per month in summer..."

"Obviously, the channels, routes and transportations have been improved over the last year..

Therefore, there is an opportunity for producers to sell products to further places."

"As the time passes by, there are more innovations. In the past, we needed to do three things with three machines. Now, we only need one machine to do everything".

infrastructure

$\begin{array}{lllllllllllllllll}\text { Rapid technological } & \sqrt{ } & \sqrt{ } & \sqrt{ } & \sqrt{ } & \sqrt{ } & \sqrt{ } & \sqrt{ } & \sqrt{ } & \sqrt{ } & \sqrt{ } & \sqrt{ } & \sqrt{ } & \sqrt{ } & \sqrt{ } & \sqrt{ } & \sqrt{ }\end{array}$

development

"We have all types of risks in here... Biological risk such as risks from pests and diseases ..."

Risks from pests and

diseases

Logistical and

infrastructure risks

Extreme weather conditions
"During the last ten years, we had very big thunderstorms. Some big thunderstorms destroyed

all the main green houses. Today, I think this is the main risk for us".

\section{Table 3 Empirical evidence for identifying AFSC risks}


Table 4 AFSC risks identified from literature

\begin{tabular}{|c|c|c|}
\hline Risk types & Risk factors & References \\
\hline Supply risks & $\begin{array}{l}\text { (1) supplier bankruptcy; (2) volatility in fertiliser cost; (3) delay in } \\
\text { securing financial support; (4) poor planning; (5) yield uncertainty; } \\
\text { (6) supplier quality problem; (7) capacity fluctuations/shortages in } \\
\text { the supply market }\end{array}$ & $\begin{array}{l}\text { Anton et al. (2011); Leat and } \\
\text { Revoredo-Giha. (2013); } \\
\text { Nyamah et al. (2017); Behzadi } \\
\text { et al. (2018); }\end{array}$ \\
\hline Demand risks & $\begin{array}{l}\text { (1) insufficient information from customers; (2) volatility of } \\
\text { customer demand; (3) market price volatility; (4) changes in food } \\
\text { safety requirements }\end{array}$ & $\begin{array}{l}\text { Dani and Deep. (2010); } \\
\text { Nyamah et al. (2017); } \\
\text { Behzadi et al. (2018); }\end{array}$ \\
\hline $\begin{array}{l}\text { Biological and } \\
\text { environmental } \\
\text { related risks }\end{array}$ & $\begin{array}{l}\text { (1) risks from pests and diseases; (2) contamination related to poor } \\
\text { sanitation and illnesses; (3) contamination affecting food safety; (4) } \\
\text { contamination and degradation of production and processing } \\
\text { processes }\end{array}$ & $\begin{array}{l}\text { Nyamah et al. (2017); Leat and } \\
\text { Revoredo-Giha. (2013) }\end{array}$ \\
\hline $\begin{array}{l}\text { Political and } \\
\text { macroeconomic } \\
\text { related risks }\end{array}$ & $\begin{array}{l}\text { (1) political instability, war, civil unrest or other socio-political } \\
\text { crises; (2) interruption of trade due to disputes with other countries; } \\
\text { (3) nationalisation/confiscation of assets, especially belonging to } \\
\text { foreign investors; (4) changes in the political environment due to } \\
\text { introduction of new laws or stipulations }\end{array}$ & $\begin{array}{l}\text { Nyamah et al. (2017); Yeboah } \\
\text { et al. (2014) }\end{array}$ \\
\hline $\begin{array}{l}\text { Weather- } \\
\text { related risks }\end{array}$ & $\begin{array}{l}\text { (1) periodic deficit/excess rainfall; (2) extreme drought; (3) } \\
\text { flooding; (4) extreme wind; (5) cold weather; (6) hailstorms }\end{array}$ & $\begin{array}{l}\text { Nyamah et al. (2017); Leat and } \\
\text { Revoredo-Giha. (2013); }\end{array}$ \\
\hline $\begin{array}{l}\text { Logistical and } \\
\text { infrastructure } \\
\text { related risks }\end{array}$ & $\begin{array}{l}\text { (1) poor infrastructure and services; (2) volatility in fuel price; (3) } \\
\text { unreliable transport; (4) changes in transportation; (5) lack of } \\
\text { infrastructure and service units; (6) poor performance of logistics } \\
\text { service providers; (7) lack of effective system integration; (8) } \\
\text { labour disputes }\end{array}$ & $\begin{array}{l}\text { Nyamah et al. (2017); Yeboah } \\
\text { et al. (2014) }\end{array}$ \\
\hline $\begin{array}{l}\text { Policy and } \\
\text { regulatory } \\
\text { risks }\end{array}$ & $\begin{array}{l}\text { (1) stricter food quality and safety standards; (2) animal welfare } \\
\text { legislation negatively affecting the competiveness; (3) potential } \\
\text { restrictions on waste disposal; (4) weak institutional capacity to } \\
\text { implement regulatory mandates }\end{array}$ & $\begin{array}{l}\text { Nyamah et al. (2017); Jaffee et } \\
\text { al. (2010) }\end{array}$ \\
\hline Financial risks & $\begin{array}{l}\text { (1) uncertain trade, market, land and tax policies; (2) inadequate } \\
\text { financial support; (3) delay in payment and even possible non- } \\
\text { payment; (4) change in exchange rate; (5) insufficient credit }\end{array}$ & $\begin{array}{l}\text { Anton et al. (2011); Bachev } \\
\text { (2017); Nyamah et al. (2017) }\end{array}$ \\
\hline $\begin{array}{l}\text { Management } \\
\text { and } \\
\text { operational } \\
\text { risks }\end{array}$ & $\begin{array}{l}\text { (1) poor management decisions on asset allocation; (2) use of } \\
\text { expired seeds; (3) poor quality control; (4) poor decision making in } \\
\text { use of inputs; (5) farm and firm equipment breakdowns; (6) } \\
\text { inability to adapt to changes in cash and labour flows (7) forecast } \\
\text { and planning errors }\end{array}$ & $\begin{array}{l}\text { Yeboah et al. (2014); Anton et } \\
\text { al. (2011); Nyamah et al. } \\
\text { (2017) }\end{array}$ \\
\hline
\end{tabular}


Table 5 Final levels of each agri-food supply chain risk

\begin{tabular}{|c|c|c|}
\hline Code & AFSC risks & Level \\
\hline $\mathbf{E 3}$ & Skill shortage & I \\
\hline E4 & Market price fluctuations & I \\
\hline E5 & Tax evasion & I \\
\hline E11 & Oral contract or agreement with partners & I \\
\hline E7 & $\begin{array}{l}\text { Lack of investment in promoting agri-food } \\
\text { products }\end{array}$ & II \\
\hline E8 & High energy costs & II \\
\hline E1 & Delay in payment & III \\
\hline E2 & Bad debts & III \\
\hline E16 & Rapid technological development & III \\
\hline E10 & Supply and demand imbalance & IV \\
\hline E6 & Risk from pests and diseases & $\mathrm{V}$ \\
\hline E9 & Poor planning & VI \\
\hline E13 & Lack of information sharing among partners & VII \\
\hline E12 & Poor agricultural infrastructure & VIII \\
\hline E14 & Extreme weather conditions & IX \\
\hline E15 & Political and economic instability & IX \\
\hline
\end{tabular}


Table 6 The fuzzy MICMAC stabilised matrix

\begin{tabular}{|c|c|c|c|c|c|c|c|c|c|c|c|c|c|c|c|c|c|}
\hline & E1 & E2 & $\mathbf{E 3}$ & E4 & E5 & E6 & E7 & E8 & E9 & E10 & E11 & E12 & E13 & E14 & E15 & E16 & $\begin{array}{c}\text { Driving } \\
\text { Power }\end{array}$ \\
\hline E1 & 0 & 0.3 & 0 & 0.3 & 0 & 0 & 0 & 0 & 0 & 0 & 0 & 0 & 0 & 0 & 0 & 0.3 & 0.9 \\
\hline E2 & 0.3 & 0 & 0.3 & 0.3 & 0.3 & 0 & 0 & 0 & 0 & 0 & 0.3 & 0 & 0 & 0 & 0 & 0.3 & 1.8 \\
\hline E3 & 0 & 0 & 0 & 0 & 0 & 0 & 0 & 0.3 & 0 & 0 & 0 & 0 & 0 & 0 & 0 & 0 & 0.3 \\
\hline E4 & 0 & 0 & 0 & 0 & 0 & 0 & 0 & 0.3 & 0 & 0 & 0 & 0 & 0 & 0 & 0 & 0 & 0.3 \\
\hline E5 & 0 & 0 & 0 & 0 & 0 & 0 & 0 & 0 & 0 & 0 & 0.3 & 0 & 0 & 0 & 0 & 0 & 0.3 \\
\hline E6 & 0.3 & 0.3 & 0.3 & 0.5 & 0.3 & 0 & 0.3 & 0 & 0 & 0 & 0 & 0 & 0 & 0 & 0 & 0 & 2 \\
\hline E7 & 0 & 0 & 0 & 0 & 0 & 0 & 0 & 0 & 0 & 0 & 0.3 & 0 & 0 & 0 & 0 & 0 & 0.3 \\
\hline E8 & 0 & 0 & 0 & 0 & 0 & 0 & 0 & 0 & 0 & 0 & 0.3 & 0 & 0 & 0 & 0 & 0 & 0.3 \\
\hline E9 & 0.3 & 0.3 & 0.5 & 0.3 & 0.3 & 0 & 0.3 & 0 & 0 & 0 & 0 & 0 & 0 & 0 & 0 & 0 & 2 \\
\hline E10 & 0.3 & 0.3 & 0.3 & 0.3 & 0.3 & 0 & 0.3 & 0 & 0 & 0 & 0 & 0 & 0 & 0 & 0 & 0 & 1.8 \\
\hline E11 & 0 & 0 & 0 & 0 & 0 & 0 & 0 & 0.3 & 0 & 0 & 0 & 0 & 0 & 0 & 0 & 0 & 0.3 \\
\hline E12 & 0.1 & 0.1 & 0.3 & 0.3 & 0.3 & 0 & 0.3 & 0.3 & 0 & 0 & 0.3 & 0 & 0 & 0 & 0 & 0.3 & 2.3 \\
\hline E13 & 0.3 & 0.3 & 0.3 & 0.3 & 0.3 & 0 & 0.3 & 0 & 0 & 0 & 0.3 & 0 & 0 & 0 & 0 & 0 & 2.1 \\
\hline E14 & 0.3 & 0.1 & 0.3 & 0.3 & 0.3 & 0 & 0.3 & 0.5 & 0 & 0.3 & 0.5 & 0 & 0 & 0 & 0 & 0.3 & 3.2 \\
\hline E15 & 0.1 & 0.3 & 0.3 & 0.3 & 0.3 & 0 & 0.3 & 0.5 & 0 & 0.3 & 0.5 & 0 & 0 & 0 & 0 & 0.3 & 3.2 \\
\hline E16 & 0 & 0 & 0 & 0.7 & 0 & 0 & 0 & 0 & 0 & 0 & 0 & 0 & 0 & 0 & 0 & 0 & 0.7 \\
\hline $\begin{array}{l}\text { Dependence } \\
\text { power }\end{array}$ & 2 & 2 & 2.6 & 3.4 & 2.4 & 0 & 2.1 & 2.2 & 0 & 0.6 & 2.8 & 0 & 0 & 0 & 0 & 1.5 & \\
\hline
\end{tabular}




\section{FIGURES}

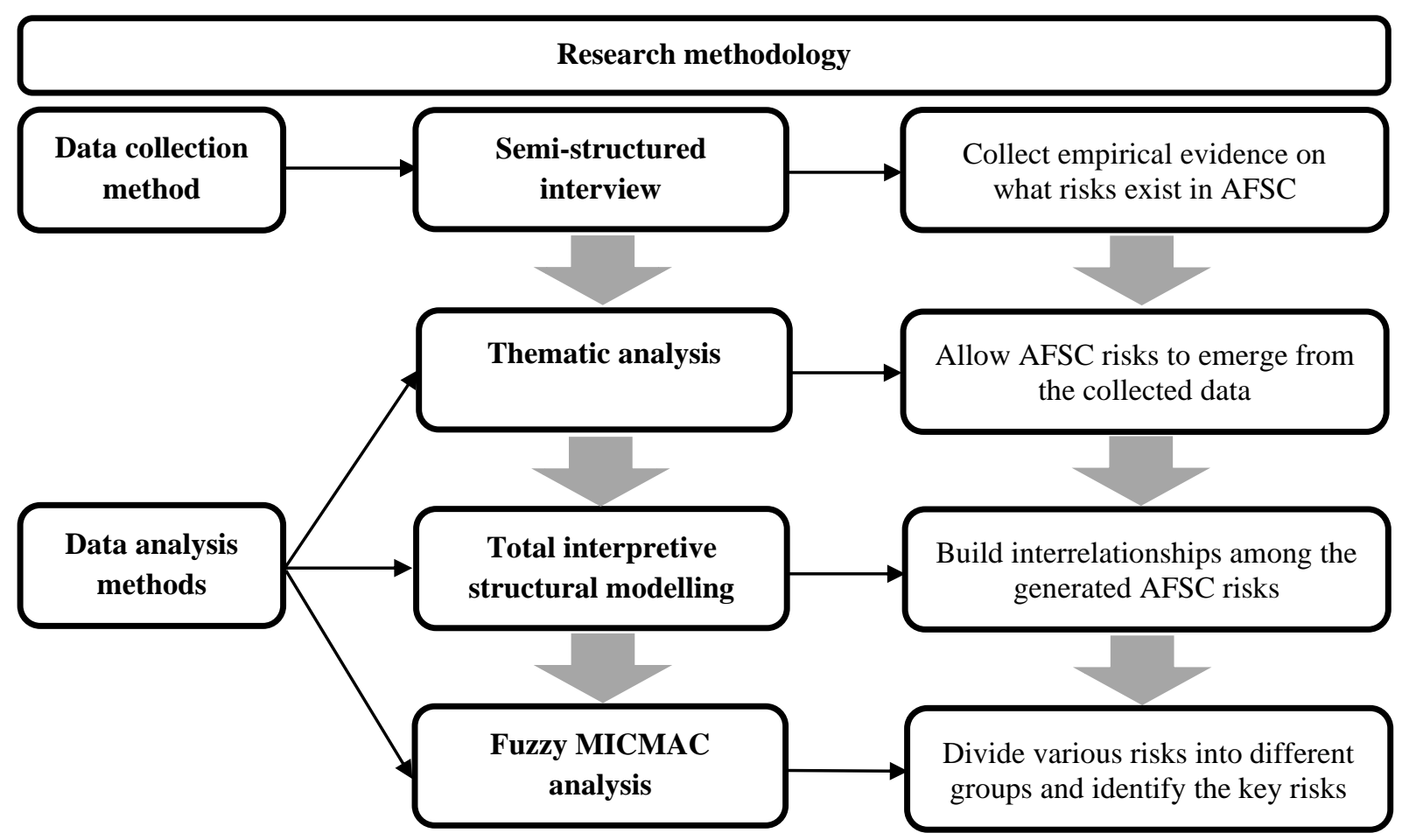

Figure 1 Research methods adopted 


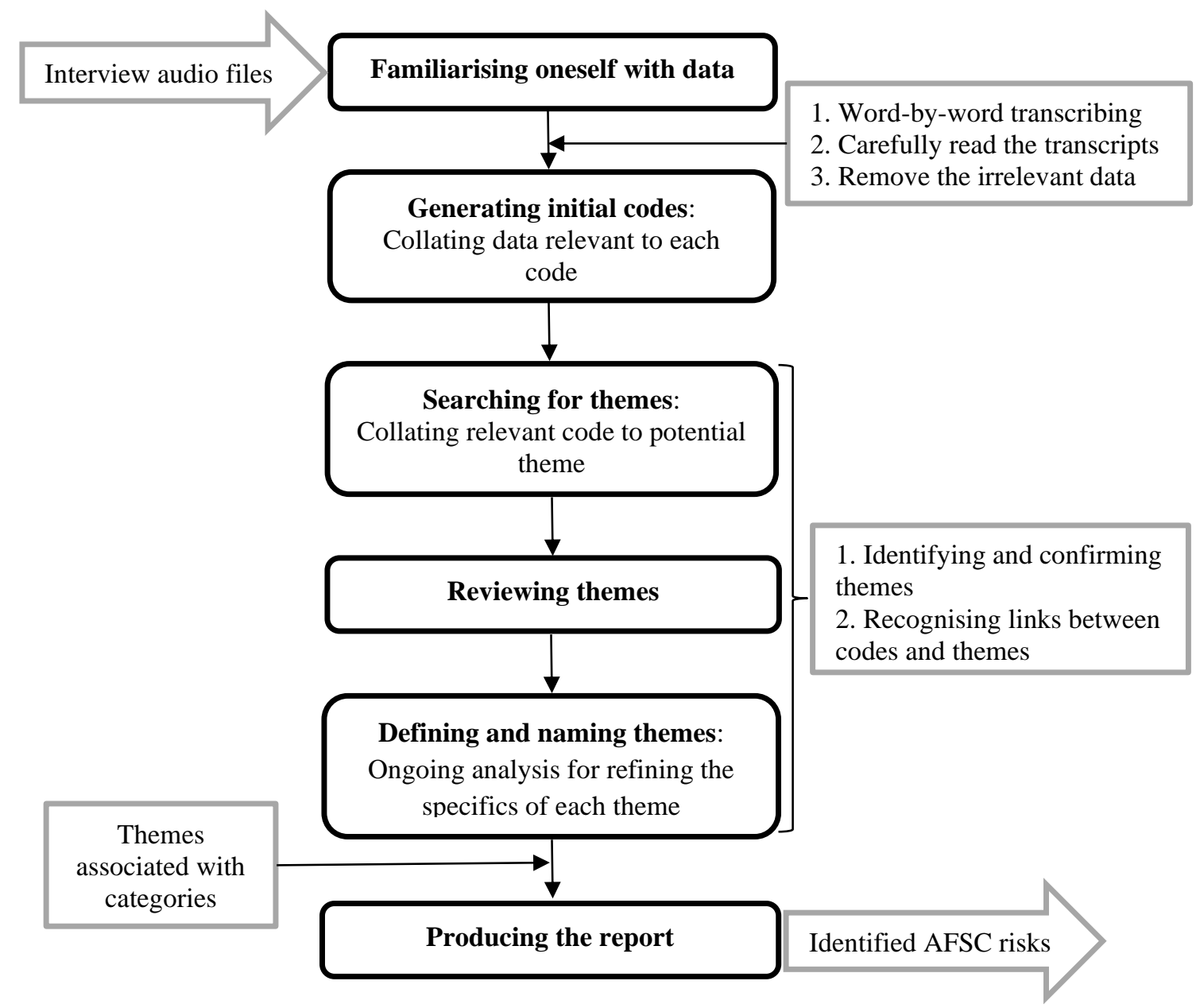

Figure 2 Thematic analysis process 


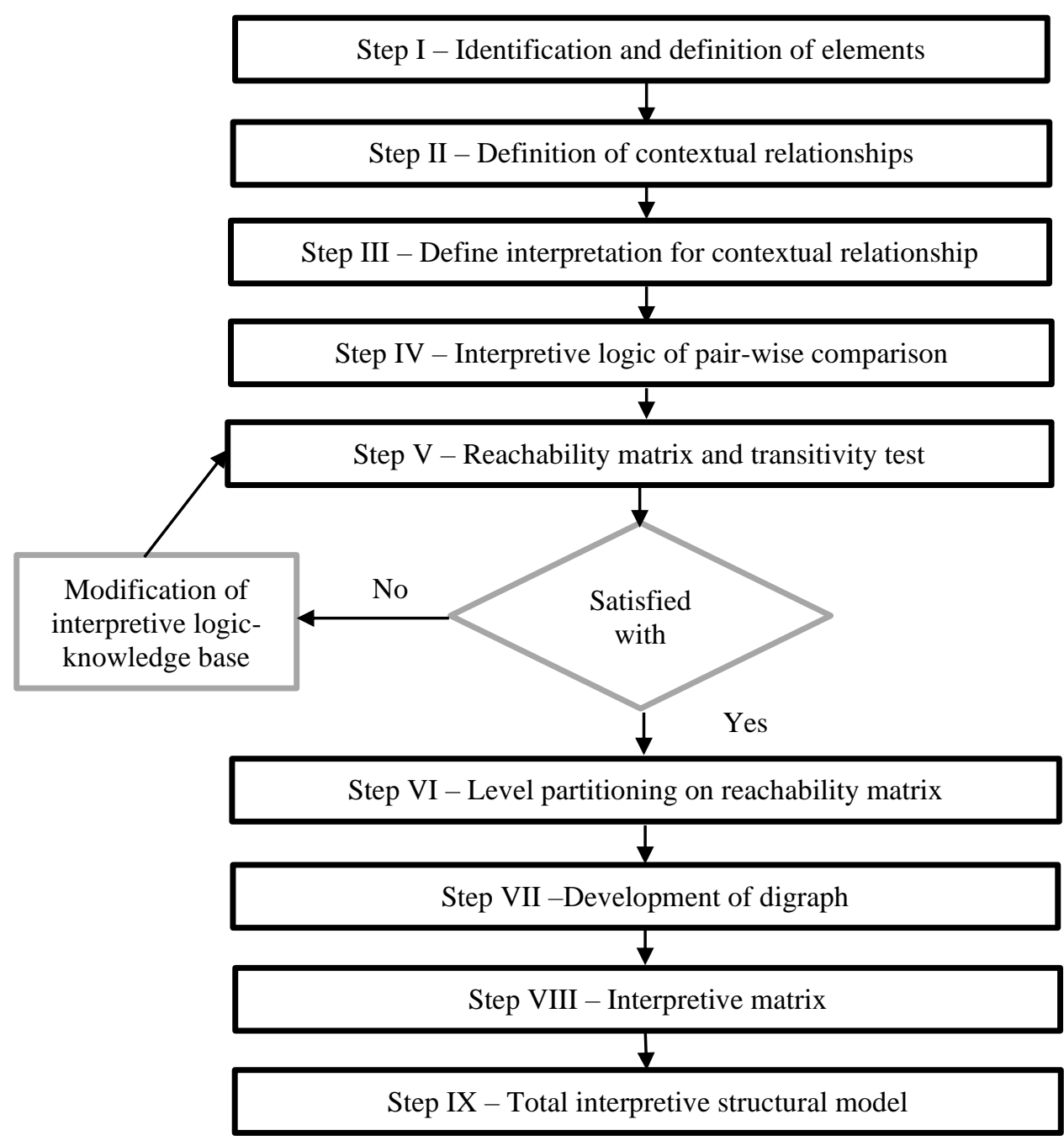

Figure 3 TISM analysis process (Note: Modified from Sushil (2012)) 


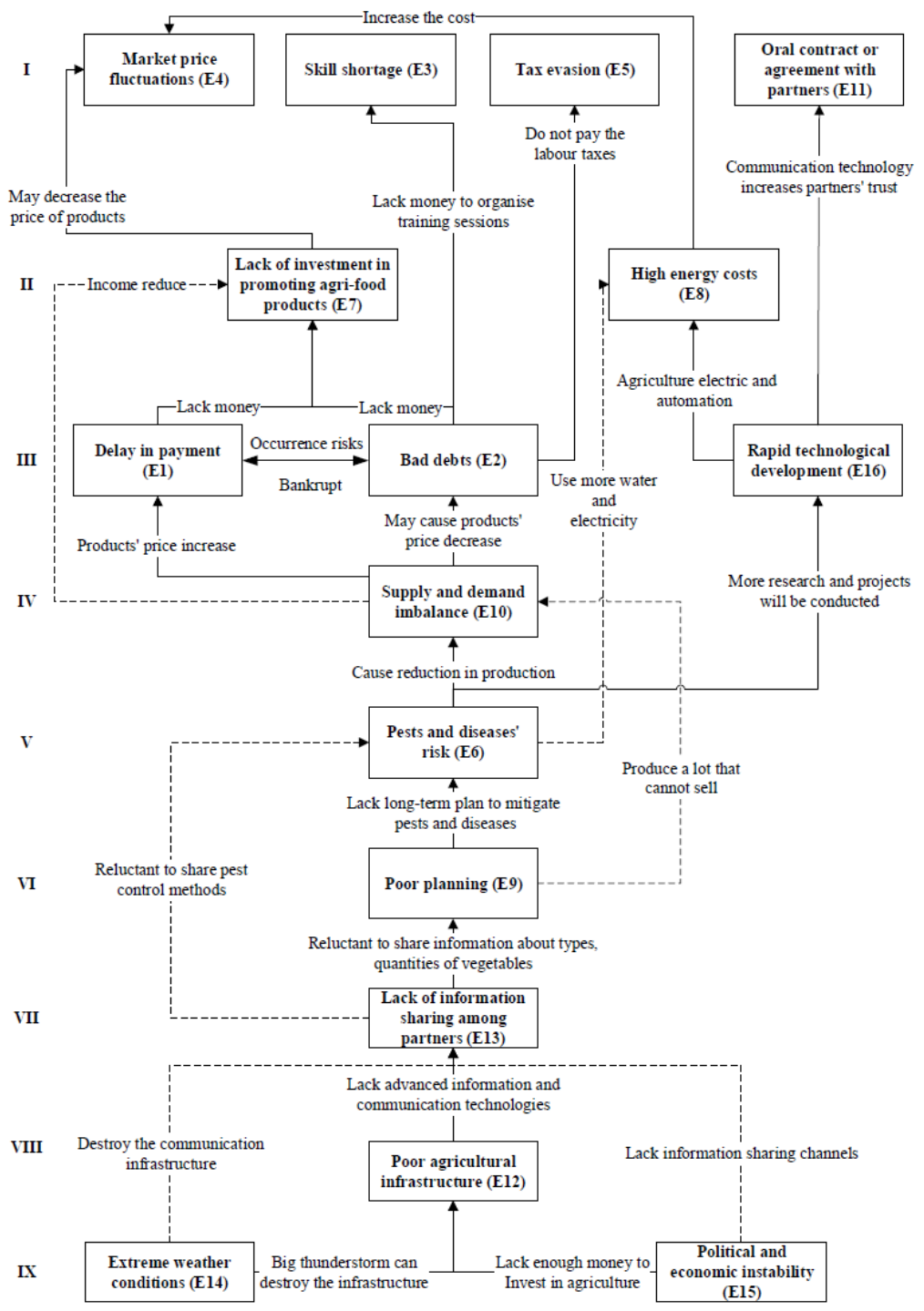

Figure 4 TISM model of AFSC risks 


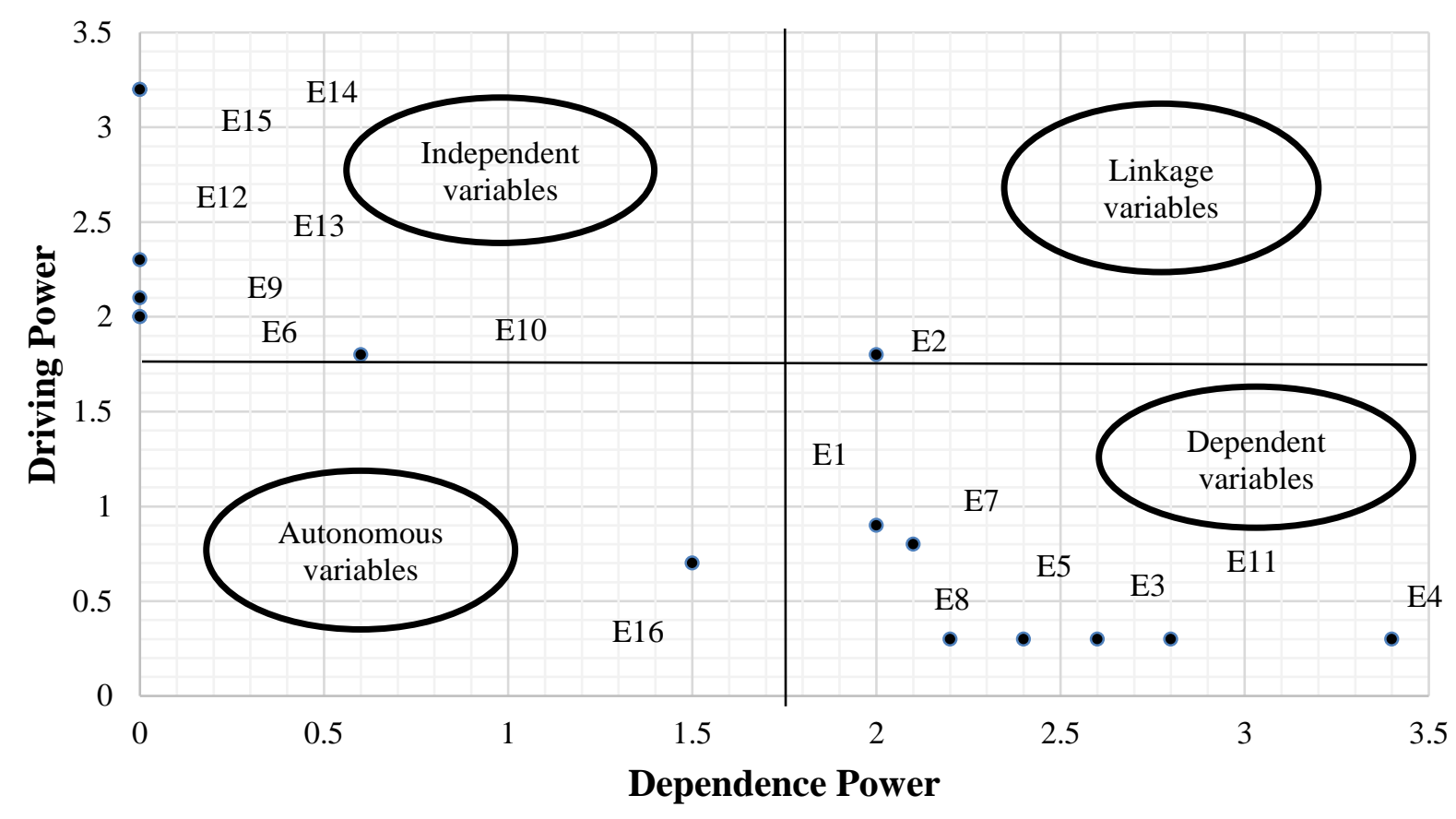

Figure 5 Classification of AFSC risks 


\section{Appendix A. Interview guide}

\section{Introductory questions}

(I) Interviewee information

a. What is your current designation?

b. Can you give me a brief overview of your job within the company operations?

c. How many years have you been working in this company?

d. How many years of your working experience in the same job role in total?

(II) Company information

e. Can you give me a brief overview of the company structure, parent company, and its operations?

$\mathrm{f}$. What is the industry sector in which the organisation operates?

g. How many employees are working for the company?

\section{A. Relationship}

(I) Relations with upstream suppliers

1. How many upstream suppliers does your company have?

2. Can you describe the functionality of the main upstream suppliers?

3. Does your company build long-term relationships with the main upstream suppliers?

4. How would you describe the relationships of your company with the upstream suppliers?

(II) Relations with downstream consumers

5. How many downstream consumers does your company have?

6. Can you describe the functionality of the main downstream consumers?

7. Does your company build long-term relationships with the main downstream consumers?

8. How would you describe the relationships of your company with the downstream consumers?

B. Risks the company faced

9. How would you describe the sources of risks that affect your company?

10. How would you describe the biggest risk that you faced in your company?

C. Risks the whole AFSC faced

11. How would you describe the sources of risks that affect the whole AFSC?
* Supply risks
* Demand risks
* Biological and environmental related risk
* Political related risk
* Weather related risk
* Logistical and infrastructure related risk
* Policy and regulatory risk
* Financial related risk
* Management and operational risk

12. How would you describe what the greatest risk for the AFSC is?

D. Risk mitigation strategies

13. How would you describe any contingency plans or personnel responsible for dealing with risks?

14. How would you describe the managerial capabilities and strategies employed to mitigate risks?

15. How would you describe the risk management plan that the company follows? (Avoidance, Mitigation, Transfer, Acceptance)

16. How would you describe how you seek to minimize the risks and spread these amongst your supply chain stakeholders? 
Appendix B. Initial reachability matrix of AFSC risks

\begin{tabular}{ccccccccccccccccc}
\hline & E1 & E2 & E3 & E4 & E5 & E6 & E7 & E8 & E9 & E10 & E11 & E12 & E13 & E14 & E15 & E16 \\
E1 & 1 & 1 & 0 & 0 & 0 & 0 & 1 & 0 & 0 & 0 & 0 & 0 & 0 & 0 & 0 & 0 \\
E2 & 1 & 1 & 1 & 0 & 1 & 0 & 1 & 0 & 0 & 0 & 0 & 0 & 0 & 0 & 0 & 0 \\
E3 & 0 & 0 & 1 & 0 & 0 & 0 & 0 & 0 & 0 & 0 & 0 & 0 & 0 & 0 & 0 & 0 \\
$\mathbf{E 4}$ & 0 & 0 & 0 & 1 & 0 & 0 & 0 & 0 & 0 & 0 & 0 & 0 & 0 & 0 & 0 & 0 \\
$\mathbf{E 5}$ & 0 & 0 & 0 & 0 & 1 & 0 & 0 & 0 & 0 & 0 & 0 & 0 & 0 & 0 & 0 & 0 \\
E6 & 1 & 1 & 0 & 1 & 0 & 1 & 1 & 0 & 0 & 1 & 0 & 0 & 0 & 0 & 0 & 1 \\
E7 & 0 & 0 & 0 & 1 & 0 & 0 & 1 & 0 & 0 & 0 & 0 & 0 & 0 & 0 & 0 & 0 \\
E8 & 0 & 0 & 0 & 1 & 0 & 0 & 0 & 1 & 0 & 0 & 0 & 0 & 0 & 0 & 0 & 0 \\
E9 & 0 & 0 & 0 & 1 & 0 & 1 & 1 & 0 & 1 & 1 & 0 & 0 & 0 & 0 & 0 & 0 \\
E10 & 1 & 1 & 0 & 1 & 0 & 0 & 0 & 0 & 0 & 1 & 0 & 0 & 0 & 0 & 0 & 0 \\
E11 & 0 & 0 & 0 & 0 & 0 & 0 & 0 & 0 & 0 & 0 & 1 & 0 & 0 & 0 & 0 & 0 \\
$\mathbf{E 1 2}$ & 0 & 0 & 0 & 0 & 0 & 0 & 0 & 0 & 0 & 1 & 0 & 1 & 1 & 0 & 0 & 0 \\
$\mathbf{E 1 3}$ & 0 & 0 & 0 & 1 & 0 & 0 & 0 & 0 & 1 & 1 & 0 & 0 & 1 & 0 & 0 & 1 \\
$\mathbf{E 1 4}$ & 0 & 0 & 0 & 1 & 0 & 1 & 1 & 1 & 0 & 1 & 0 & 1 & 0 & 1 & 0 & 0 \\
E15 & 0 & 0 & 0 & 1 & 1 & 0 & 1 & 0 & 0 & 1 & 0 & 1 & 0 & 0 & 1 & 0 \\
E16 & 0 & 0 & 1 & 1 & 0 & 0 & 0 & 1 & 0 & 0 & 1 & 0 & 0 & 0 & 0 & 1 \\
\hline
\end{tabular}


Appendix C. Final reachability matrix of AFSC risks

\begin{tabular}{|c|c|c|c|c|c|c|c|c|c|c|c|c|c|c|c|c|}
\hline & E1 & E2 & E3 & E4 & E5 & E6 & E7 & E8 & E9 & E10 & E11 & E12 & E13 & E14 & E15 & E16 \\
\hline E1 & 1 & 1 & $1 *$ & $1 *$ & $1 *$ & 0 & 1 & 0 & 0 & 0 & 0 & 0 & 0 & 0 & 0 & 0 \\
\hline E2 & 1 & 1 & 1 & $1^{*}$ & 1 & 0 & 1 & 0 & 0 & 0 & 0 & 0 & 0 & 0 & 0 & 0 \\
\hline E3 & 0 & 0 & 1 & 0 & 0 & 0 & 0 & 0 & 0 & 0 & 0 & 0 & 0 & 0 & 0 & 0 \\
\hline E4 & 0 & 0 & 0 & 1 & 0 & 0 & 0 & 0 & 0 & 0 & 0 & 0 & 0 & 0 & 0 & 0 \\
\hline E5 & 0 & 0 & 0 & 0 & 1 & 0 & 0 & 0 & 0 & 0 & 0 & 0 & 0 & 0 & 0 & 0 \\
\hline E6 & 1 & 1 & $1 *$ & 1 & $1 *$ & 1 & 1 & $1^{*}$ & 0 & 1 & $1 *$ & 0 & 0 & 0 & 0 & 1 \\
\hline E7 & 0 & 0 & 0 & 1 & 0 & 0 & 1 & 0 & 0 & 0 & 0 & 0 & 0 & 0 & 0 & 0 \\
\hline E8 & 0 & 0 & 0 & 1 & 0 & 0 & 0 & 1 & 0 & 0 & 0 & 0 & 0 & 0 & 0 & 0 \\
\hline E9 & $1 *$ & $1 *$ & $1 *$ & 1 & $1 *$ & 1 & 1 & $1^{*}$ & 1 & 1 & $1 *$ & 0 & 0 & 0 & 0 & $1^{*}$ \\
\hline E10 & 1 & 1 & $1 *$ & 1 & $1 *$ & 0 & $1^{*}$ & 0 & 0 & 1 & 0 & 0 & 0 & 0 & 0 & 0 \\
\hline E11 & 0 & 0 & 0 & 0 & 0 & 0 & 0 & 0 & 0 & 0 & 1 & 0 & 0 & 0 & 0 & 0 \\
\hline E12 & $1 *$ & $1 *$ & $1 *$ & $1 *$ & $1 *$ & 0 & $1^{*}$ & 0 & 0 & 1 & 0 & 1 & 1 & 0 & 0 & 0 \\
\hline E13 & $1^{*}$ & $1^{*}$ & $1 *$ & 1 & $1 *$ & $1 *$ & $1 *$ & $1 *$ & 1 & 1 & $1 *$ & 0 & 1 & 0 & 0 & 0 \\
\hline E14 & $1 *$ & $1 *$ & $1 *$ & 1 & $1 *$ & 1 & 1 & 1 & 0 & 1 & $1 *$ & 1 & $1^{*}$ & 1 & 0 & $1^{*}$ \\
\hline E15 & $1 *$ & $1 *$ & $1 *$ & 1 & 1 & $1 *$ & 1 & $1 *$ & $1 *$ & 1 & $1 *$ & 1 & $1 *$ & 0 & 1 & $1 *$ \\
\hline E16 & 0 & 0 & 1 & 1 & 0 & 0 & 0 & 1 & 0 & 0 & 1 & 0 & 0 & 0 & 0 & 1 \\
\hline
\end{tabular}


Appendix D. Partitioning the reachability matrix into different levels

\begin{tabular}{|c|c|c|c|c|}
\hline VARIABLE & REACHABILITY SET (RS) & ANTECEDENT SET (AS) & $\mathbf{R S} \cap \mathbf{A S}$ & $\begin{array}{c}\text { LEVE } \\
\text { L }\end{array}$ \\
\hline \multicolumn{5}{|l|}{ ITERATION 1} \\
\hline E1 & $1,2,3,4,5,7$ & $1,2,6,9,10,12,13,14,15$ & 1,2 & \\
\hline E2 & $1,2,3,4,5,7$ & $1,2,6,9,10,12,13,14,15$ & 1,2 & \\
\hline $\mathbf{E 3}$ & 3 & $1,2,3,6,9,10,12,13,14,15,16$ & 3 & I \\
\hline $\mathbf{E 4}$ & 4 & $1,2,4,6,7,8,9,10,12,13,14,15,16$ & 4 & I \\
\hline E5 & 5 & $1,2,5,6,9,10,12,13,14,15$ & 5 & I \\
\hline E6 & $1,2,3,4,5,6,7,8,10,11,16$ & $6,9,13,14,15,16$ & 6,16 & \\
\hline E7 & 4,7 & $1,2,6,7,9,10,12,13,14,15$ & 7 & \\
\hline E8 & 4,8 & $6,8,9,13,14,15,16$ & 8 & \\
\hline E9 & $1,2,3,4,5,6,7,8,9,10,11,16$ & $9,13,15$ & 9 & \\
\hline E10 & $1,2,3,4,5,7,10$ & $6,9,10,12,13,14,15$ & 10 & \\
\hline E11 & 11 & $6,9,11,13,14,15,16$ & 11 & I \\
\hline E12 & $1,2,3,4,5,7,10,12,13$ & $12,14,15$ & 12 & \\
\hline E13 & $1,2,3,4,5,6,7,8,9,10,11,13,16$ & $12,13,14,15$ & 13 & \\
\hline E14 & $1,2,3,4,5,6,7,8,10,11,12,13,14,16$ & 14 & 14 & \\
\hline E15 & $1,2,3,4,5,6,7,8,9,10,11,12,13,15,16$ & 15 & 15 & \\
\hline E16 & $3,4,8,11,16$ & $6,9,13,14,15,16$ & 16 & \\
\hline \multicolumn{5}{|l|}{ ITERATION 2} \\
\hline E1 & $1,2,7$ & $1,2,6,9,10,12,13,14,15$ & 1,2 & \\
\hline $\mathbf{E 2}$ & $1,2,7$ & $1,2,6,9,10,12,13,14,15$ & 1,2 & \\
\hline E6 & $1,2,6,7,8,10,16$ & $6,9,13,14,15,16$ & 6,16 & \\
\hline E7 & 7 & $1,2,6,7,9,10,12,13,14,15$ & 7 & II \\
\hline E8 & 8 & $6,8,9,13,14,15,16$ & 8 & II \\
\hline E9 & $1,2,6,7,8,9,10,16$ & $9,13,15$ & 9 & \\
\hline E10 & $1,2,7,10$ & $6,9,10,12,13,14,15$ & 10 & \\
\hline E12 & $1,2,7,10,12,13$ & $12,14,15$ & 12 & \\
\hline E13 & $1,2,6,7,8,9,10,13,16$ & $12,13,14,15$ & 13 & \\
\hline E14 & $1,2,6,7,8,10,12,13,14,16$ & 14 & 14 & \\
\hline E15 & $1,2,6,7,8,9,10,12,13,15,16$ & 15 & 15 & \\
\hline E16 & 8,16 & $6,9,13,14,15,16$ & 16 & \\
\hline \multicolumn{5}{|l|}{ ITERATION 3} \\
\hline E1 & 1,2 & $1,2,6,9,10,12,13,14,15$ & 1,2 & III \\
\hline E2 & 1,2 & $1,2,6,9,10,12,13,14,15$ & 1,2 & III \\
\hline E6 & $1,2,6,10,16$ & $6,9,13,14,15,16$ & 6,16 & \\
\hline E9 & $1,2,6,9,10,16$ & $9,13,15$ & 9 & \\
\hline E10 & $1,2,10$ & $6,9,10,12,13,14,15$ & 10 & \\
\hline E12 & $1,2,10,12,13$ & $12,14,15$ & 12 & \\
\hline E13 & $1,2,6,9,10,13,16$ & $12,13,14,15$ & 13 & \\
\hline E14 & $1,2,6,10,12,13,14,16$ & 14 & 14 & \\
\hline E15 & $1,2,6,9,10,12,13,15,16$ & 15 & 15 & \\
\hline E16 & 16 & $6,9,13,14,15,16$ & 16 & III \\
\hline \multicolumn{5}{|l|}{ ITERATION 4} \\
\hline E6 & 6,10 & $6,9,13,14,15$ & 6 & \\
\hline E9 & $6,9,10$ & $9,13,15$ & 9 & \\
\hline E10 & 10 & $6,9,10,12,13,14,15$ & 10 & IV \\
\hline E12 & $10,12,13$ & $12,14,15$ & 12 & \\
\hline E13 & $6,9,10,13$ & $12,13,14,15$ & 13 & \\
\hline E14 & $6,10,12,13,14$ & 14 & 14 & \\
\hline E15 & $6,9,10,12,13,15$ & 15 & 15 & \\
\hline \multicolumn{5}{|l|}{ ITERATION 5} \\
\hline E6 & 6 & $6,9,13,14,15$ & 6 & $\mathbf{V}$ \\
\hline E9 & 6,9 & $9,13,15$ & 9 & \\
\hline E12 & 12,13 & $12,14,15$ & 12 & \\
\hline E13 & $6,9,13$ & $12,13,14,15$ & 13 & \\
\hline E14 & $6,12,13,14$ & 14 & 14 & \\
\hline E15 & $6,9,12,13,15$ & 15 & 15 & \\
\hline \multicolumn{5}{|l|}{ ITERATION 6} \\
\hline E9 & 9 & $9,13,15$ & 9 & VI \\
\hline E12 & 12,13 & $12,14,15$ & 12 & \\
\hline E13 & 9,13 & $12,13,14,15$ & 13 & \\
\hline E14 & $12,13,14$ & 14 & 14 & \\
\hline E15 & $9,12,13,15$ & 15 & 15 & \\
\hline \multicolumn{5}{|l|}{ ITERATION 7} \\
\hline E12 & 12,13 & $12,14,15$ & 12 & \\
\hline E13 & 13 & $12,13,14,15$ & 13 & VII \\
\hline E14 & $12,13,14$ & 14 & 14 & \\
\hline E15 & $12,13,15$ & 15 & 15 & \\
\hline \multicolumn{5}{|l|}{ ITERATION 8} \\
\hline E12 & 12 & $12,14,15$ & 12 & VIII \\
\hline E14 & 12,14 & 14 & 14 & \\
\hline E15 & 12,15 & 15 & 15 & \\
\hline
\end{tabular}


ITERATION 9 
Appendix E. Binary direct reachability matrix

\begin{tabular}{ccccccccccccccccc}
\hline & E1 & E2 & E3 & E4 & E5 & E6 & E7 & E8 & E9 & E10 & E11 & E12 & E13 & E14 & E15 & E16 \\
E1 & 0 & 1 & 0 & 0 & 0 & 0 & 1 & 0 & 0 & 0 & 0 & 0 & 0 & 0 & 0 & 0 \\
E2 & 1 & 0 & 1 & 0 & 1 & 0 & 1 & 0 & 0 & 0 & 0 & 0 & 0 & 0 & 0 & 0 \\
E3 & 0 & 0 & 0 & 0 & 0 & 0 & 0 & 0 & 0 & 0 & 0 & 0 & 0 & 0 & 0 & 0 \\
$\mathbf{E 4}$ & 0 & 0 & 0 & 0 & 0 & 0 & 0 & 0 & 0 & 0 & 0 & 0 & 0 & 0 & 0 & 0 \\
$\mathbf{E 5}$ & 0 & 0 & 0 & 0 & 0 & 0 & 0 & 0 & 0 & 0 & 0 & 0 & 0 & 0 & 0 & 0 \\
E6 & 1 & 1 & 0 & 1 & 0 & 0 & 1 & 0 & 0 & 1 & 0 & 0 & 0 & 0 & 0 & 1 \\
E7 & 0 & 0 & 0 & 1 & 0 & 0 & 0 & 0 & 0 & 0 & 0 & 0 & 0 & 0 & 0 & 0 \\
E8 & 0 & 0 & 0 & 1 & 0 & 0 & 0 & 0 & 0 & 0 & 0 & 0 & 0 & 0 & 0 & 0 \\
E9 & 0 & 0 & 0 & 1 & 0 & 1 & 1 & 0 & 0 & 1 & 0 & 0 & 0 & 0 & 0 & 0 \\
E10 & 1 & 1 & 0 & 1 & 0 & 0 & 0 & 0 & 0 & 0 & 0 & 0 & 0 & 0 & 0 & 0 \\
E11 & 0 & 0 & 0 & 0 & 0 & 0 & 0 & 0 & 0 & 0 & 0 & 0 & 0 & 0 & 0 & 0 \\
E12 & 0 & 0 & 0 & 0 & 0 & 0 & 0 & 0 & 0 & 1 & 0 & 0 & 1 & 0 & 0 & 0 \\
$\mathbf{E 1 3}$ & 0 & 0 & 0 & 1 & 0 & 0 & 0 & 0 & 1 & 1 & 0 & 0 & 0 & 0 & 0 & 1 \\
$\mathbf{E 1 4}$ & 0 & 0 & 0 & 1 & 0 & 1 & 1 & 1 & 0 & 1 & 0 & 1 & 0 & 0 & 0 & 0 \\
E15 & 0 & 0 & 0 & 1 & 1 & 0 & 1 & 0 & 0 & 1 & 0 & 1 & 0 & 0 & 0 & 0 \\
E16 & 0 & 0 & 1 & 1 & 0 & 0 & 0 & 1 & 0 & 0 & 1 & 0 & 0 & 0 & 0 & 0 \\
\hline
\end{tabular}


Appendix F. Fuzzy direct reachability matrix

\begin{tabular}{|c|c|c|c|c|c|c|c|c|c|c|c|c|c|c|c|c|}
\hline & E1 & E2 & E3 & E4 & E5 & E6 & E7 & E8 & E9 & E10 & E11 & E12 & E13 & E14 & E15 & E16 \\
\hline E1 & 0 & 0.3 & 0 & 0 & 0 & 0 & 0.3 & 0 & 0 & 0 & 0 & 0 & 0 & 0 & 0 & 0 \\
\hline E2 & 0.9 & 0 & 0.7 & 0 & 0.7 & 0 & 0.7 & 0 & 0 & 0 & 0 & 0 & 0 & 0 & 0 & 0 \\
\hline E3 & 0 & 0 & 0 & 0 & 0 & 0 & 0 & 0 & 0 & 0 & 0 & 0 & 0 & 0 & 0 & 0 \\
\hline E4 & 0 & 0 & 0 & 0 & 0 & 0 & 0 & 0 & 0 & 0 & 0 & 0 & 0 & 0 & 0 & 0 \\
\hline E5 & 0 & 0 & 0 & 0 & 0 & 0 & 0 & 0 & 0 & 0 & 0 & 0 & 0 & 0 & 0 & 0 \\
\hline E6 & 0.5 & 0.3 & 0 & 0.7 & 0 & 0 & 0.5 & 0 & 0 & 0.3 & 0 & 0 & 0 & 0 & 0 & 0.7 \\
\hline E7 & 0 & 0 & 0 & 0.7 & 0 & 0 & 0 & 0 & 0 & 0 & 0 & 0 & 0 & 0 & 0 & 0 \\
\hline E8 & 0 & 0 & 0 & 0.7 & 0 & 0 & 0 & 0 & 0 & 0 & 0 & 0 & 0 & 0 & 0 & 0 \\
\hline E9 & 0 & 0 & 0 & 0.9 & 0 & 0.7 & 0.9 & 0 & 0 & 0.7 & 0 & 0 & 0 & 0 & 0 & 0 \\
\hline E10 & 0.7 & 0.5 & 0 & 0.9 & 0 & 0 & 0 & 0 & 0 & 0 & 0 & 0 & 0 & 0 & 0 & 0 \\
\hline E11 & 0 & 0 & 0 & 0 & 0 & 0 & 0 & 0 & 0 & 0 & 0 & 0 & 0 & 0 & 0 & 0 \\
\hline E12 & 0 & 0 & 0 & 0 & 0 & 0 & 0 & 0 & 0 & 0.3 & 0 & 0 & 0.3 & 0 & 0 & 0 \\
\hline E13 & 0 & 0 & 0 & 0.3 & 0 & 0 & 0 & 0 & 0.3 & 0.7 & 0 & 0 & 0 & 0 & 0 & 0.3 \\
\hline E14 & 0 & 0 & 0 & 0.7 & 0 & 0.3 & 0.3 & 0.7 & 0 & 0.7 & 0.7 & 0.9 & 0 & 0 & 0 & 0 \\
\hline E15 & 0 & 0 & 0 & 0.7 & 0.9 & 0 & 0.5 & 0 & 0 & 0.3 & 0 & 0.5 & 0 & 0 & 0 & 0 \\
\hline E16 & 0 & 0 & 0.7 & 0.3 & 0 & 0 & 0 & 0.7 & 0 & 0 & 0.5 & 0 & 0 & 0 & 0 & 0 \\
\hline
\end{tabular}

